WHC-SP-1105, Rev. 2

UC-600

\title{
Fire Protection Program Fiscal Year 1996 Site Support Program Plan Hanford Fire Department
}

D. E. Good

Date Published

September 1995

Prepared for the U.S. Department of Energy

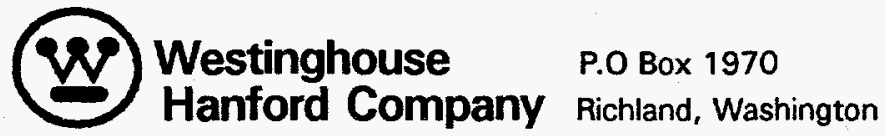

Management and Operations Contractor for the

U.S. Department of Energy under Contract DE-AC06-87RL10930

Approved for Public Release 
LECAL DISCLAMER

This report was prepared as an account of work sponsored by an agency of the United States Government. Neither the

United States Government nor any agency thereof, nor any of

their employees, nor any of their contractors, subcontractors

or their employees, makes any warranty, express or implied,

or assumes any legal liability or responsibility for the

accuracy, completeness, or any third party's use or the results

of such use of any information, apparatus, product, or process

disclosed, or represents that its use would not infringe

privately owned rights. Reference herein to any specific

commercial product, process, or service by trade name,

trademark, manufacturer, or otherwise, does not necessarily

constitute or imply its endorsement, recommendation, or

favoring by the United States Government or any agency

thereof or its contractors or subcontractors. The views and

opinions of authors expressed herein do not necessarily state

or reflect those of the United States Government or any

agency thereof.

This report has been reproduced from the best available copy. Available in paper copy and microfiche.

\section{Available to the U.S. Department of Energy}

and its contractors from

Office of Scientific and Technical Information

P.O. Box 62

Oak Ridge, TN 37831

(615) 576-8401

Printed in the United States of America

DISCLM-3.CHP (1-91) 


\section{DISCLAMMER}

Portions of this document may be illegible in electronic image products. Images are produced from the best available original document. 


\section{Fire Protection Program Fiscal Year 1996 Site Support Program Plan Hanford Fire Department}

Prepared for the U.S. Department of Energy

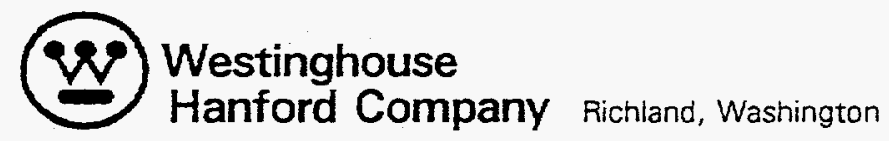

Management and Operations and Engineering Contractor for the

U.S. Department of Energy under Contract DE-ACO6-87RL 10930 
WHC-SP-1105, Rev 2

Site SuPPORT Program Plan APPROVAL SHEET

FiRE PROTECTION PROGRAM - WHC 6.7.2.2

Assistant Manager - Contracting Officer's Representative
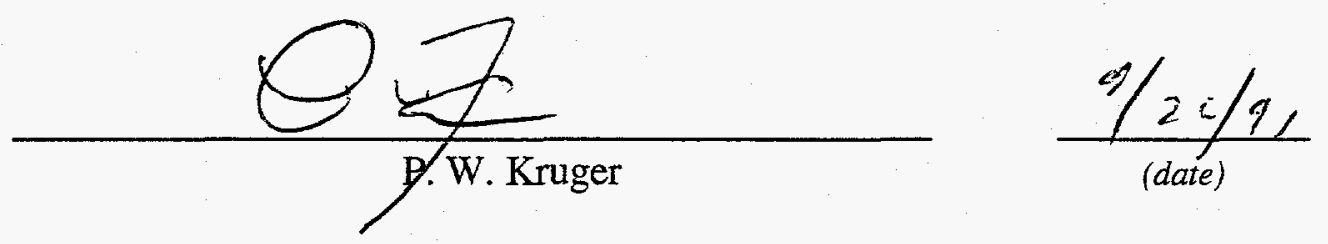

RL Program Manager

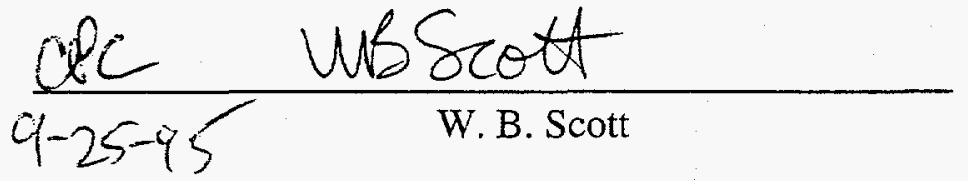

$\frac{9 / 26 / 95}{(\text { date })}$
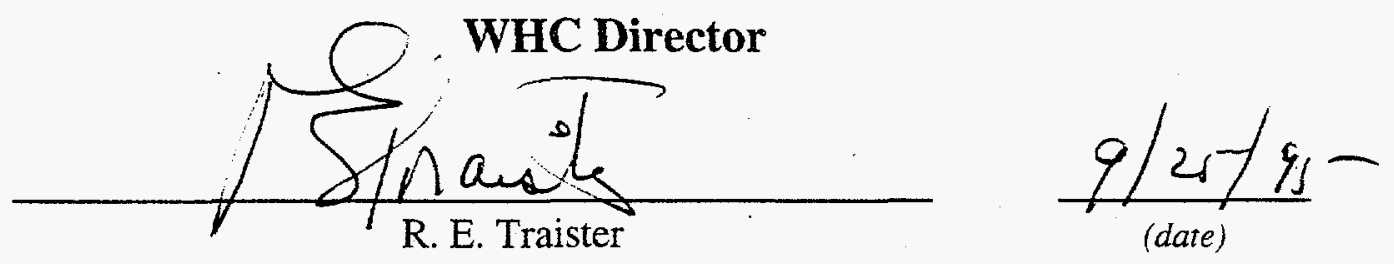

WHC Program Manager

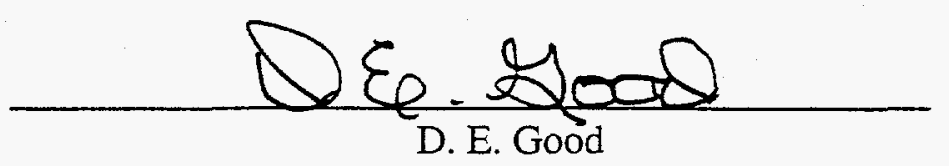

$\frac{9 / 2,5 / 95}{(\text { date })}$ 


\section{RELEASE AUTHORIZATION}

Document Number: WHC-SP-1105, Rev 2

Document Title: $\quad$ Fire Protection Program Fiscal Year 1996 Site

Support Program Plan - Hanford Fire Department

Release Date: $\quad 9 / 15 / 95$

This document was reviewed following the procedures described in WHC-CM-3-4 and is:

APPROVED FOR PUBLIC RELEASE

WHC Information Release Administration Specialist:

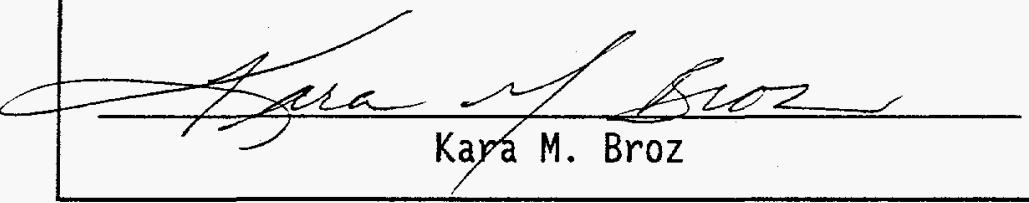

Available to the public from the U.S. Department of Commerce National Technical Information Services

5285 Port Royal Road

Springfield, Va 22161

(703) $487-4650$ 


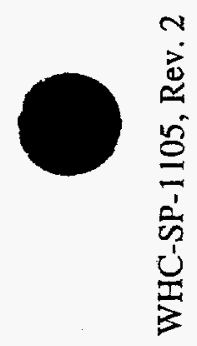

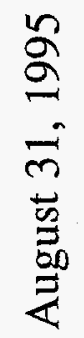

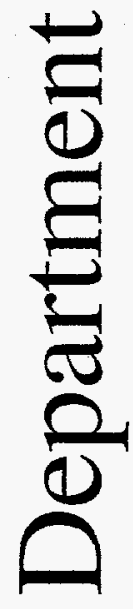

1

$T$

0

6

$\sigma$

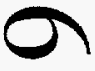

5

$\mathrm{O}$

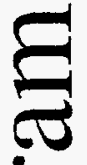

an

${ }_{10}^{+\infty}$
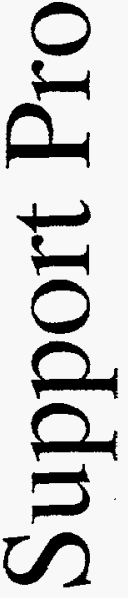

$\frac{1}{62}$

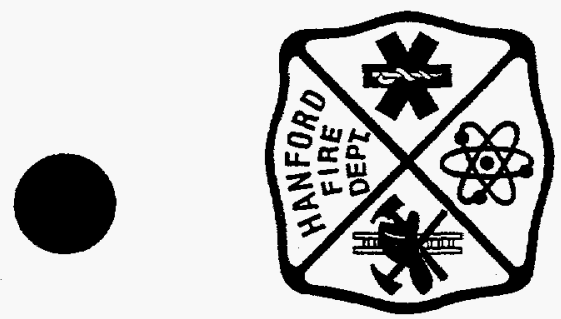


Table of Contents

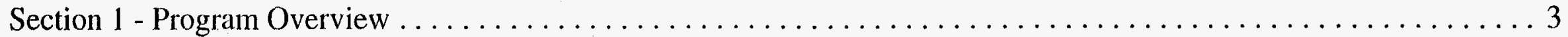

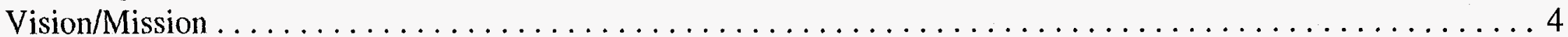

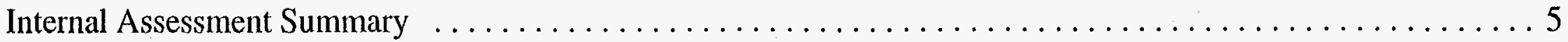

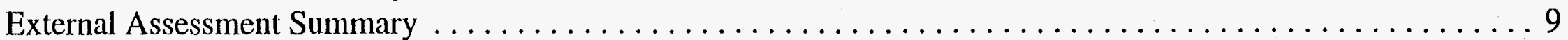

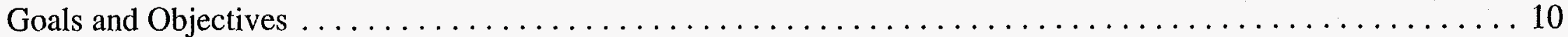

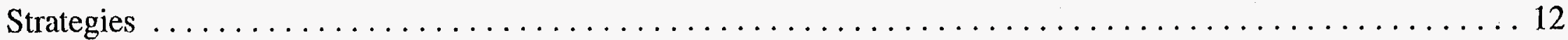

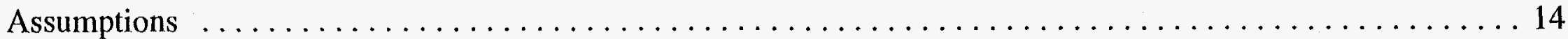

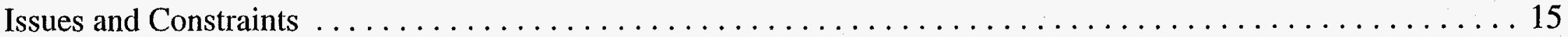

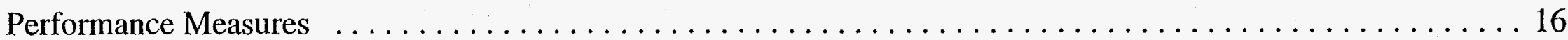

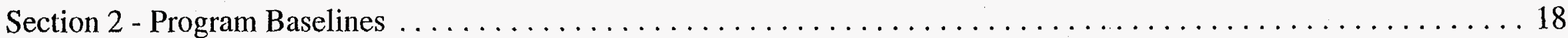

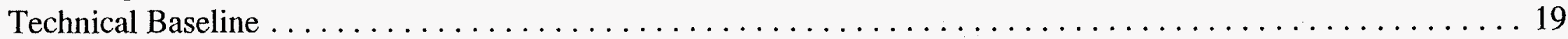

Work Breakdown Structure and Responsibility Assignment Matrix $\ldots \ldots \ldots \ldots \ldots \ldots \ldots \ldots \ldots \ldots$

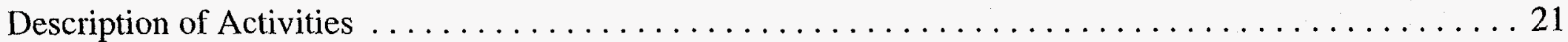

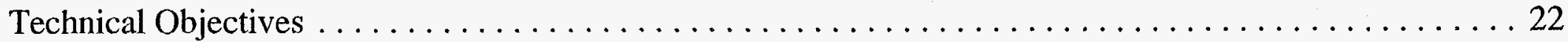

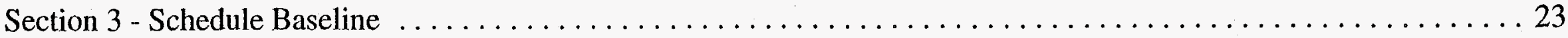

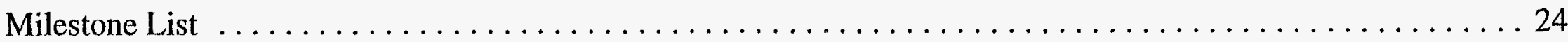

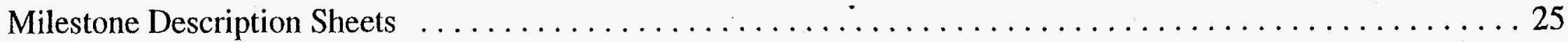

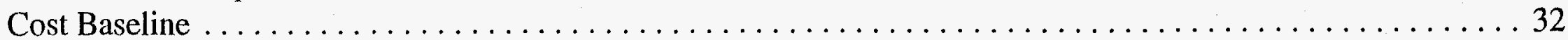

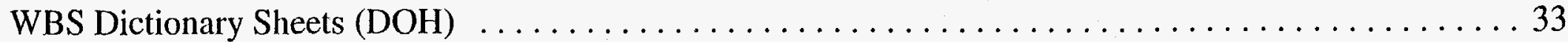

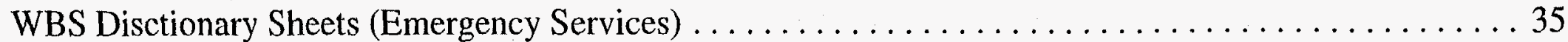

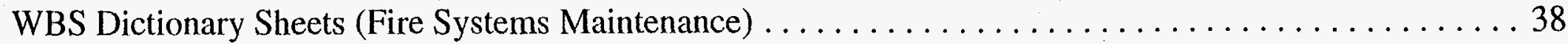

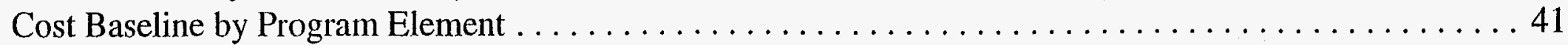

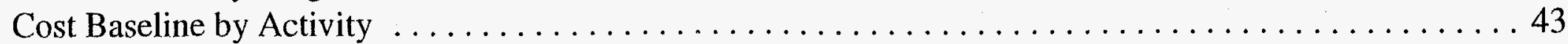

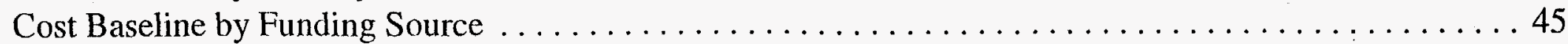

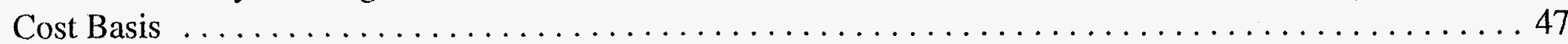

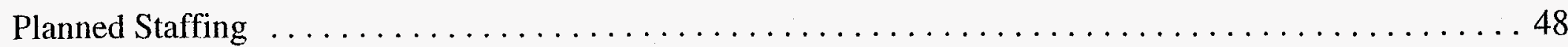




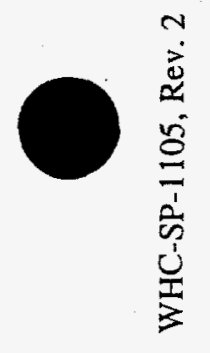
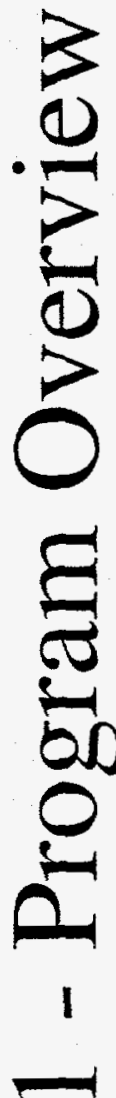

$\frac{5}{6}$ 


\begin{tabular}{|l|c|c|}
\hline 1.A Vision/Mission & $\begin{array}{c}\text { Westinghouse Hanford Company } \\
\text { Hanford Fire Department } \\
\text { Program Plan }\end{array}$ & $\begin{array}{c}\text { FY 1996 } \\
\text { Site Support Program Plan }\end{array}$ \\
\hline
\end{tabular}

The mission of the Hanford Fire Department (HFD) is to support the safe and timely cleanup of the Hanford site by providing fire suppression, fire prevention, emergency rescue, emergency medical service, and hazardous materials response; and to be capable of dealing with and terminating emergency situations which could threaten the operations, employees, or interest of the U.S. Department of Energy operated Hanford Site. This includes response to surrounding fire departments/districts under a mutual aid agreement and contractual fire fighting, hazardous materials, and ambulance support to Washington Public Power Supply System (Supply System). The fire department also provides site fire marshal overview authority, fire system testing and maintenance, self-contained breathing apparatus maintenance, building tours and inspections, ignitable and reactive waste site inspections, prefire planning, and employee fire prevention education. 


\begin{tabular}{|l|c|c|}
\hline 1.B.1 Internal Assessment Summary & $\begin{array}{c}\text { Westinghouse Hanford Company } \\
\text { Hanford Fire Department } \\
\text { Program Plan } \\
\text { SMS/WBS No. 6.7.2.2 }\end{array}$ & $\begin{array}{c}\text { FY 1996 } \\
\text { Site Support Program Plan }\end{array}$ \\
\hline
\end{tabular}

\section{PRIMARY CUSTOMERS}

Fire department services are provided to all Hanford DOE contractors and programs, sub-contractors, the Washington Public Power Supply System, the Bonneville Power Administration, and surrounding communities via mutual aid agreements.

\section{PRODUCTS/SERVICES PROVIDED}

The fire department provides life safety and property protection services on a 24 hour a day, 7 day-a-week basis and services which assure fire system operability through the call-in of fire systems maintenance personnel to repair emergency failures.

\section{MAJOR ACTIVITIES PERFORMED TO DELIVERY PRODUCTS AND SERVICES}

The specific activities and services performed by the fire department are described below:

Fire Suppression: In firefighting operations, the fire department's fire suppression effectiveness is put to the ultimate test. All of the activities used by the fire department must come together on the fireground. The HFD is trained, staff, and equipped to suppress any credible fire threat to the Hanford site. This includes special purpose building fires, structure fires, nuclear facility fires, and range or wildland fires.

Emergency Rescue: Rescue operations are the most important consideration at any fire or emergency incident and is the only acceptable reason for exposing firefighters to otherwise unnecessary risks. Hanford fire crews maintain the capability for emergency rescue from fire, building collapse, excavation cave in, confined space, vehicle accidents, and any other accident scenario requiring rescue services. 


\begin{tabular}{|c|c|c|}
\hline $\begin{array}{c}\text { 1.B.1 Internal Assessment Summary } \\
\text { (cont.) }\end{array}$ & $\begin{array}{c}\text { Westinghouse Hanford Company } \\
\text { Hanford Fire Department } \\
\text { Program Plan } \\
\text { SMS/WBS No. 6.7.2.2 }\end{array}$ & $\begin{array}{c}\text { FY } 1996 \\
\text { Site Support Program Plan }\end{array}$ \\
\hline
\end{tabular}

Emergency Medical Services: These services are provided by utilizing the fire suppression personnel and cross-training them to be able to perform these essential life support tasks. These services includes basic and advanced life support. Basic life support is generally limited to airway maintenance, ventilatory (breathing) support, CPR (cardio-pulmonary resuscitation), hemorrhage control, splinting of fractures, management of spinal injuries, stabilization and transportation of the patient. Advanced life support services include all basic life support measures plus invasive medical procedures, including: intravenous therapy; cardiac defibrillation; administration of antiarrhythmic medications and other specific drugs, medications, and solutions; use of adjunctive ventilation devices; and all other procedures authorized by Washington State Law.

Hazardous Materials Response: This additional service is provided to the Hanford Site by utilizing selected suppression personnel, who are cross-trained and certified to perform this essential activity. Included in this service is emergency response to all site hazardous material spills and releases for control actions. These actions involve containment, confinement, and termination of emergency situations to best protect the site employees and the environment.

Mutual Aid Response: This service is provided through written fire suppression and emergency medical plans and agreements with 10 different agencies, including surrounding fire districts, cities, and counties. Also included is a contractual agreement for firefighting and ambulance support to the Washington Public Power Supply System.

Fire System Testing and Maintenance: Fire alarm, fire suppression, and fire water distribution system testing is a service provided to all Hanford site DOE contractors and agencies. This same group, provides maintenance and repair services for all Westinghouse Hanford Company (WHC) facilities, for those ICF Kaiser facilities that were previously managed by WHC, Bechtel, the Bonneville Power Administration Ashe Substation, and the 313 Building operated by Kaiser Aluminum. These services include: functional testing of fire systems components, systems and devices in 526 Hanford buildings and facilities; and corrective and preventive maintenance of approximately 19,238 fire alarm and suppression system devices.

Self-Contained Breathing Apparatus (SCBA) maintenance and servicing: This service is provided to all Hanford contractors who own and operate SCBAs. The service includes annual and biannual inspections and functional tests of each of the approximately 550 SCBA units and over 600 high pressure breathing air cylinders located throughout the Hanford Site plus cleaning and recharging units and cylinders as required. 


\begin{tabular}{|c|c|c|}
\hline $\begin{array}{l}\text { 1.B.1 Internal Assessment Summary } \\
\text { (cont.) }\end{array}$ & $\begin{array}{c}\text { Westinghouse Hanford Company } \\
\text { Hanford Fire Department } \\
\text { Program Plan } \\
\text { SMS/WBS No. 6.7.2.2 }\end{array}$ & $\begin{array}{c}\text { FY } 1996 \\
\text { Site Support Program Plan }\end{array}$ \\
\hline
\end{tabular}

Eire Prevention Program: This program is specifically authorized by DOE-RL and is administered as a part of the site fire protection program by the fire marshal. The fire marshal provides fire prevention, fire investigation, and fire and life safety education services using nationally recognized codes and standards. The prevention of fire causes and the ability to reduce potential injuries and to minimize losses when fires do occur is of the utmost priority.

\section{EVALUATION OF MAJOR ACTIVITIES (COST. VALUE-ADDED. ETC.)}

The services provided by the HFD, contribute directly to the safety of site personnel and facilities. Property loss is kept to a minimum, and personnel sickness or injuries are reduced in severity by providing prompt response of a well trained emergency response organization. Costs of services are shared by contractors through the common support pool and are kept very reasonable by having one organization with many cross-trained people able to fill a number of different emergency roles. Fire systems are tested and maintained to the requirements of national codes and standards by an efficient and cost effective organization established in response to a value engineering activity.

Building Tours and Inspections: Tours and inspections are conducted to familiarize suppression firefighters with building contents and any construction hazards of Hanford facilities and construction sites. These inspections include looking for code violations and potential fire hazards.

Prefire Planning: A prefire plan is an essential survey of a potential fire hazard and a plan for fighting a fire that might strike a particular occupancy or facility. This service is provided by the fire suppression personnel and is a sitewide service. The prefire planning process involves four steps: 1) information gathering; 2) information analysis; 3) information dissemination, and 4) review and fire scene training drills. The individual facility/building layout showing access routes, dimensions, fire systems, exposures, and fire hydrants. Details include the type of occupancy, special volatile materials and construction of adjacent buildings and the best position to station fire apparatus in relation to water supply, space, grade, and to protect exposures. 


\begin{tabular}{|c|c|c|}
\hline 1.B.1 Internal Assessment Summary \\
(cont.) & $\begin{array}{c}\text { Westinghouse Hanford Company } \\
\text { Hanford Fire Department }\end{array}$ & $\begin{array}{c}\text { FY 1996 } \\
\text { Program Plan }\end{array}$ \\
& SMS/WBS No. 6.7.2.2 & \\
\hline
\end{tabular}

\section{EACTORS WHICH INFLUENCE RESOURCE CONSUMPTION (CHANGES TO COST AND VOLUME)}

$\square$ When facilities are deactivated their fire systems typically remain in service and require testing and maintenance. These facilities also require continued fire protection.

$\square$ As testing and maintenance requirements (defined by NFPA codes and standards) change, the cost of compliance changes. In recent years, the trend has been slightly upward.

$\square$ During building demolition, the risk of worker injury increases, often necessitating the pre-positioning of an on-the-scene ambulance and rescue team or mobile first aid facility. Because of these factors the staffing and funding requirements of the HFD are expected to remain near constant or grow slightly over the next five years.

\section{EACTORS THAT INELUENCE CHANGES IN TYPES OR NATURE OF PRODUCTS AND SERVICES}

The type and nature of the services provided by the fire department will vary slightly as the site population, and site mission changes with more emphasis placed on medical and rescue operations associated with the higher risk clean-up mission and demolition, recovery of structural materials, and construction. New buildings and systems are being activated while others are being removed from service with a net result of not much change for the foreseable future.

Occasional changes to National Fire Protection Association (NFPA) codes and standards, Washington Administrative Codes (WACs), CFR/OSHA requirements, or DOE Orders can cause significant impacts to the type and quantity of services required. Such changes are part of the FY 1996 budget request, which factors in the cost of coming into compliance with several different NFPA codes and standards which have recently changed. 


\begin{tabular}{|l|c|c|}
\hline & $\begin{array}{c}\text { Westinghouse Hanford Company } \\
\text { Hanford Fire Department } \\
\text { Program Plan }\end{array}$ & FY 1996 \\
& SMS/WBS No. 6.7.2.2 & Site Support Program Plan \\
\hline
\end{tabular}

\section{SUMMARY OF CUSTOMER REQUIREMENTS (NEEDS)}

The Hanford Fire Department meets the needs of our DOE and contractor customers by providing timely emergency response services, reliable systems through testing and maintenance of fire systems, and an active fire prevention program. Meetings with DOE-RL occur several times monthly and meetings with site contractors occur at least twice monthly. These meetings are used as forums to discuss issues and services and to assure our services meet customer expectations. Formal assessments such as Value Engineering studies, external audits, and third party assessments are scheduled periodically to assure that our capabilities continue to meet customer desires and the requirements of DOE orders and appropriate national codes and standards. A 3rd party assessment of site risks is being conducted in FY 1996 at the request of RL. The results of this assessment will be used to help determine the site emergency service requirements now and in the future. Also during FY 1996, the HFD will participate in meetings with the City of Richland and RL to discuss emergency services needs and operations. WHC will not provide recommendations or judgements for fire department transitioning and outsourcing.

\section{OTHER EXTERNAL CHALLENGES}

As customer missions change, the HFD responds. For example, the increase in decontamination and decommissioning activities has previously prompted HFD to acquire an additional ambulance and crews to standby during the conduct of potentially hazardous demolition tasks. As private or non-DOE governmental agencies move on site or as site activities are privatized, HFD is negotiating to provide a full range of services to these entities. These services are currently being provided to the Washington Public Power Supply System reactor complex and Kaiser Aluminum (in the 300 Area's 313 Building). During FY 1996, service agreements are expected to be finalized with the Laser Interferometer Gravitational Wave Observatory (LIGO), the 400 Area facilities leased by the Port of Benton County (Washington), and with the Tank Waste Remediation System (TWRS) (if TWRS is privatized). 



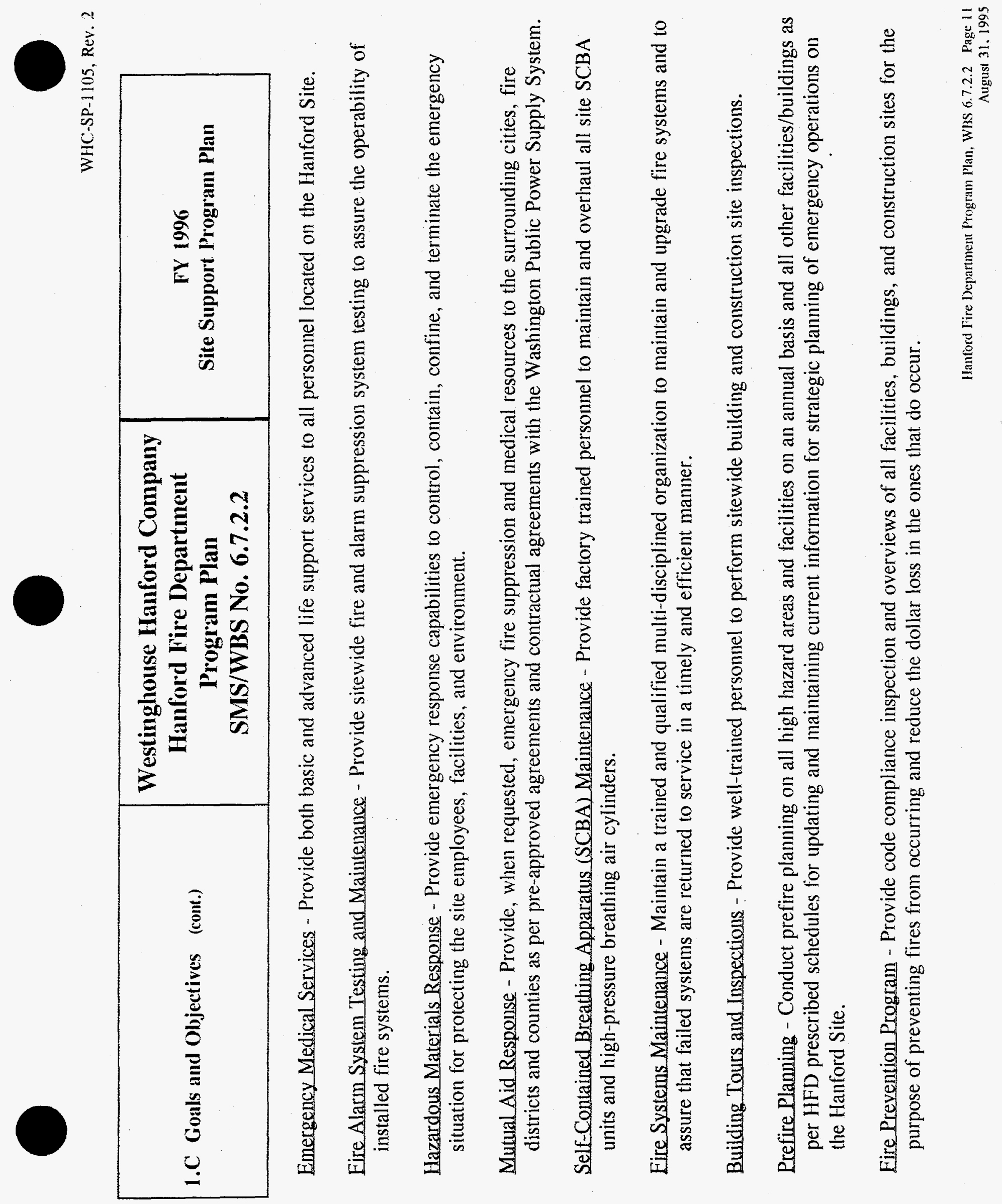




\begin{tabular}{|l|c|c|}
\hline 1.D Strategies & $\begin{array}{c}\text { Westinghouse Hanford Company } \\
\text { Hanford Fire Department }\end{array}$ & $\begin{array}{c}\text { FY 1996 } \\
\text { Program Plan }\end{array}$ \\
& SMS/WBS No. 6.7.2.2 & \\
\hline
\end{tabular}

\section{CUSTOMER SUPPORT STRATEGIES}

$\sqrt{ }$ Provide fire suppression, emergency rescue, emergency medical services, hazardous materials response capabilities, building tours and inspections, prefire planning, and fire prevention activities from the 200 Area fire station with a 24-hour per day pumper crew and ambulance crew.

$\checkmark$ Provide fire suppression, emergency rescue, emergency medical services, building tours and inspections, prefire planning, and fire prevention activities from the 400 Area fire station with a 24-hour per day pumper crew and ambulance crew.

$\sqrt{ }$ Provide fire suppression, emergency rescue, emergency medical services, hazardous materials response, capabilities, building tours and inspections, prefire planning, and fire prevention activities from the 300 Area fire station with a 24-hour per day pumper crew and ambulance crew.

$\checkmark$ Provide fire system testing and maintenance support to customer organizations through a single multi-craft, multi-disciplined organization staffed with craft, engineers, planners/schedulers, and firefighters.

$\sqrt{ }$ Provide fire suppression, emergency rescue, emergency medical services, building tours and inspections, prefire planning, and fire prevention activities from the 100 Area fire station with a 24-hour per day pumper crew and ambulance crew.

$\sqrt{ }$ Provide a fire prevention program for the purpose of preventing most site fires from occurring and reducing the losses of the ones that do occur.

$\sqrt{ }$ Provide direct-funded fire protection system maintenance support for maintaining WHC fire alarm systems and components. 


\begin{tabular}{|l|c|c|}
\hline 1.D Strategies (cont.) & $\begin{array}{c}\text { Westinghouse Hanford Company } \\
\text { Hanford Fire Department } \\
\text { Program Plan }\end{array}$ & $\begin{array}{c}\text { FY 1996 } \\
\text { Site Support Program Plan } \\
\text { SMS/WBS No. 6.7.2.2 }\end{array}$ \\
\hline
\end{tabular}

$\sqrt{ }$ Provide 24-hour-a-day dispatch capabilities. This task encompasses the timely dispatch of emergency responses to both onsite emergencies and offsite mutual aid emergencies.

$\sqrt{ }$ Provide emergency command officers for on-the-scene command of site emergencies and control of the fireground operations.

$\sqrt{ }$ Provide innovative program management through diversification and utilization of all available resources. Program management has adapted to the change-oriented environment and will remain in line with the new mission at Hanford.

$\sqrt{ }$ Remain efficient and cost-effective through continuous periodic self-assessment, customer feedback, and external assessment by independent third party sources.

\section{QRGANIZATION AND MANAGEMENT STRATEGIES}

Constantly seek self-improvement through employee involvement in an enthusiastic total quality program encompassing the WHC productivity improvement program, the Behavior Based Safety Program, the Voluntary Protection Program, self-assessments, and team building. 
WHC-SP-1 105, Rev. 2

\begin{tabular}{|l|c|c|}
\hline 1.E Assumptions & $\begin{array}{c}\text { Westinghouse Hanford Company } \\
\text { Hanford Fire Department } \\
\text { Program Plan }\end{array}$ & $\begin{array}{c}\text { FY 1996 } \\
\text { SMS/WBS No. 6.7.2.2 }\end{array}$ \\
\hline
\end{tabular}

$\sqrt{ }$ The level and type of services provided to site contractors in FY 1996 will be consistant with service levels for FY 1995.

$\sqrt{ }$ HFD will continue to supply the same range of services as currently provided in the 313 building for Kaiser Aluminum company and for the Washington Public Power Supply System complex.. 


\begin{tabular}{|l|c|c|}
\hline 1.F Issues and Constraints & $\begin{array}{c}\text { Westinghouse Hanford Company } \\
\text { Hanford Fire Department } \\
\text { Program Plan } \\
\text { SMS/WBS No. 6.7.2.2 }\end{array}$ & $\begin{array}{c}\text { FY 1996 } \\
\text { Site Support Program Plan }\end{array}$ \\
\hline
\end{tabular}

$\checkmark$ Implementation of the new NFPA 1582 Firefighter Medical Requirements will require a risk management review by Legal and Labor Relations regarding the impacts of this new standard on the existing work force; i.e., firefighters and managers.

$\sqrt{ }$ Implementation of the NFPA 1500 physical fitness requirements for firefighters will require negotiations with HAMTC firefighters and a risk management review by Legal and Labor Relations regarding the impacts on the existing work force; i.e., firefighters and managers.

$\sqrt{ }$ It is anticipated that during this fiscal year, HFD personnel will be asked to participate in the HAZWOPER emergency response demonstration pilot and other HAMMER-related support activities. That workscope is not included in this plan and will have to be addressed via change control once task scoping activities are completed. Fixed staffing levels will result in this work having a significant impact on other planned tasks by key department personnel.

$\sqrt{ }$ Activities are currently underway that are expected to result in a transfer of some respiratory protection workscope to the HFD early in FY 1996. If and when this transfer occurs, the SSPP will be modified to reflect the changes in budget and FTEs.

$\sqrt{ }$ Privatization and economic transition activities are expected to accelerate this fiscal year and the planning and special studies associated with them will be an unplanned impact to departmental workscope and budget. The scope and cost of these activities will be addressed via change control as appropriate. 


\begin{tabular}{|l|c|c|}
\hline 1.G Performance Measures & $\begin{array}{c}\text { Westinghouse Hanford Company } \\
\text { Hanford Fire Department }\end{array}$ \\
Program Plan & FY 1996 \\
SMS/WBS No. 6.7.2.2 & Site Support Program Plan \\
\hline
\end{tabular}

The fire department routinely reports on several different performance measures. The specific performance measures reported, the frequency report, and the organizations reported to are provided below:

\section{Performance Measures}

Fire Alarm Responses

Ambulance Runs

Cost Reduction Proposal Status

\section{SCBA Maintenance Statistics}

Training; given and received

Complete $100 \%$ of fire system testing for the year

Complete $85 \%$ of fire systems preventive maintenance for the year

\section{Report Frequency \\ Organization Reported To}

Monthly

Monthly

Weekly

Monthly

Monthly

Monthly

Monthly

Monthly
Building Managers, WHC-Senior Staff, and DOE-RL Building Managers, WHC-Senior Staff, and DOE-RL

Department Manager and Division Manager DOE-RL

Building Managers, WHC-Senior Staff, and DOE-RL

Building Managers, WHC-Senior Staff, and DOE-RL

Building Managers, WHC-Senior Staff, and DOE-RL

Building Managers, WHC-Senior Staff, and DOE-RL 
旁

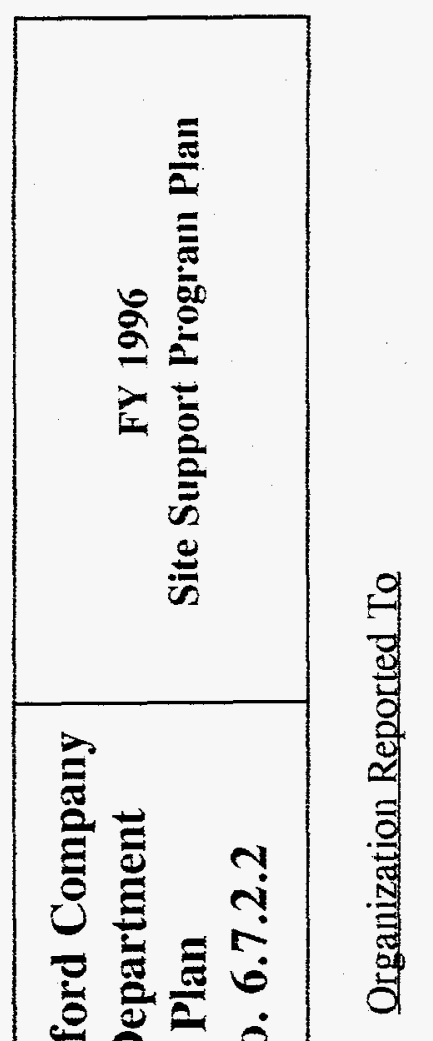

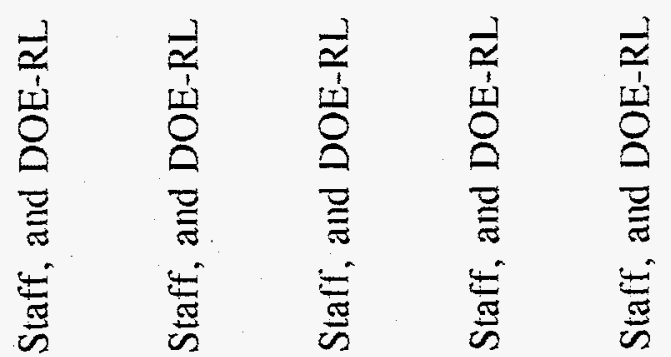

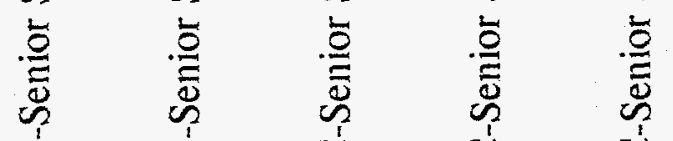

光 婇

$=\frac{a}{2}$

至

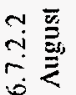

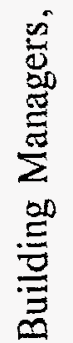

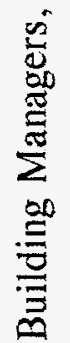

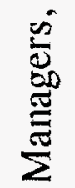

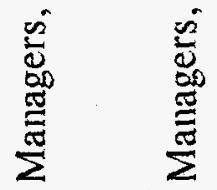

产

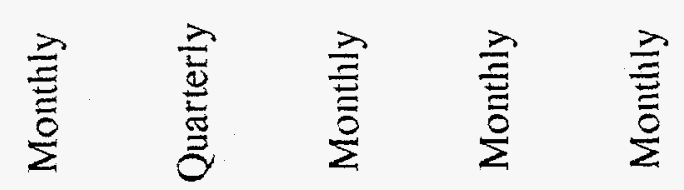

혈

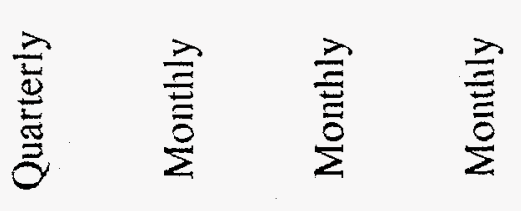

蒿

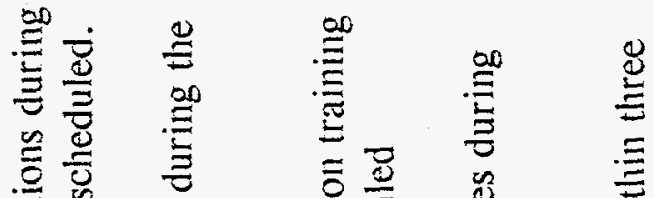

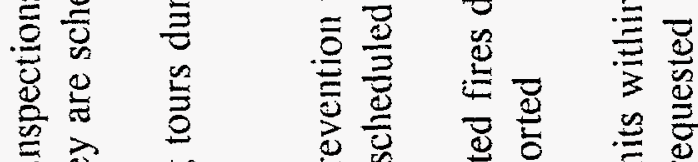

$\frac{\mathscr{Z}}{3}$

至

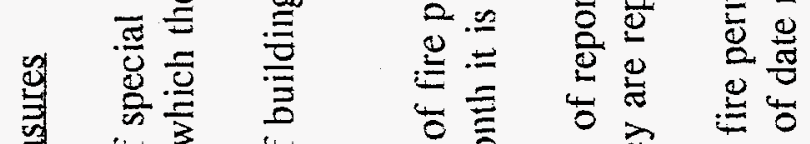

$\div 3$ 岁

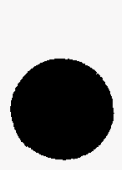

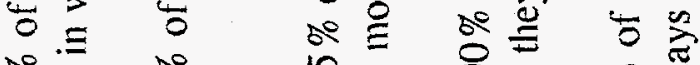

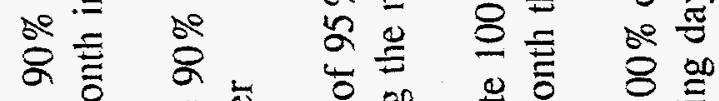

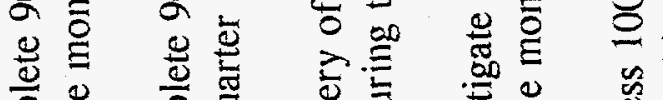

总焉

5 
○旁

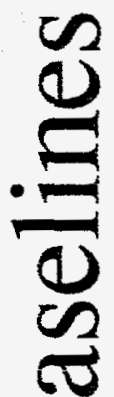

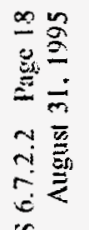

$\underline{2}$

$\mathrm{O}$

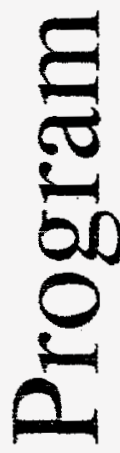

I

C)

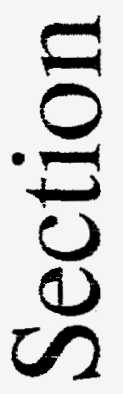


○高

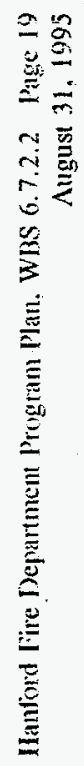

$\frac{1}{10}$

0

a

5 
○

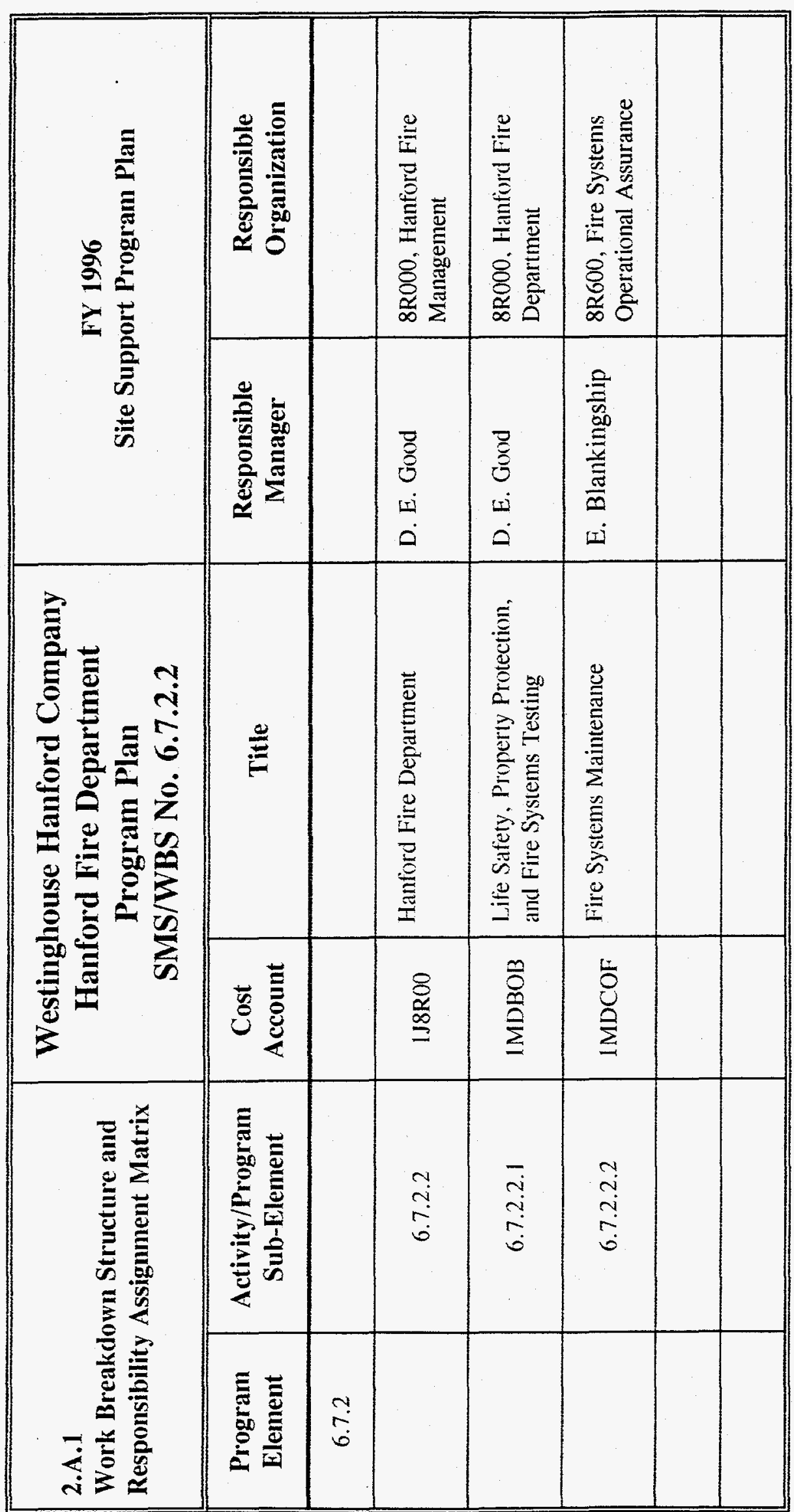




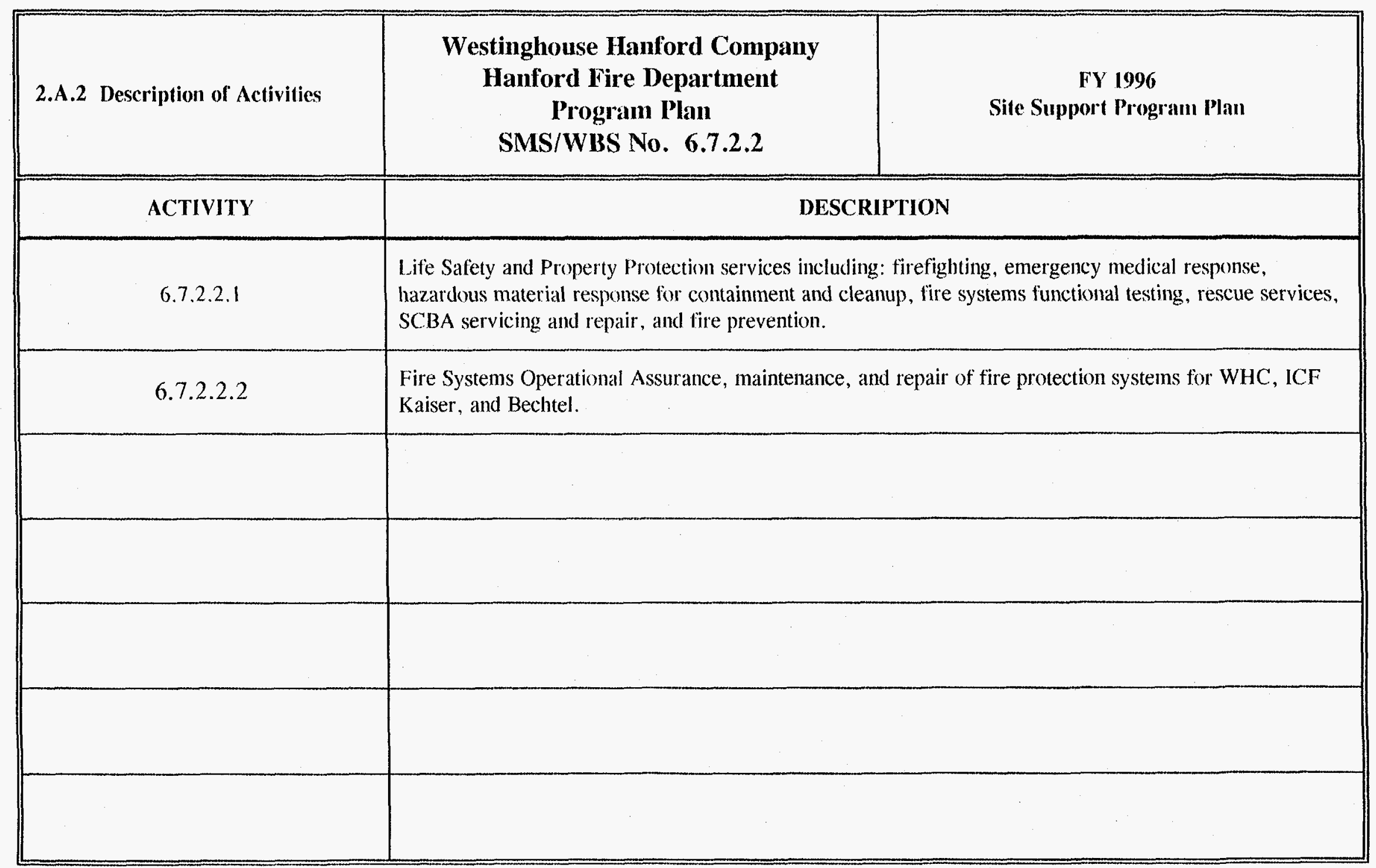




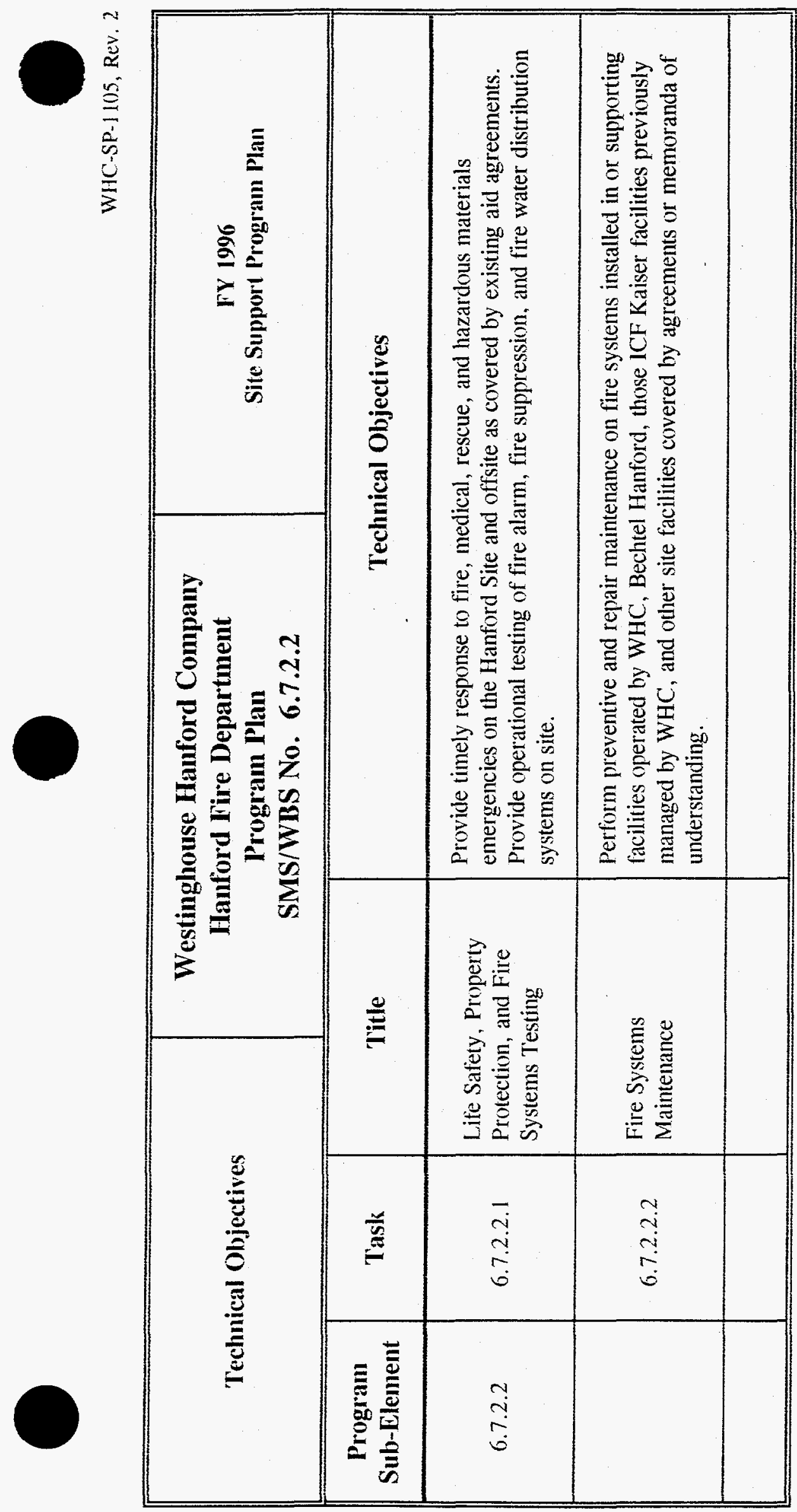

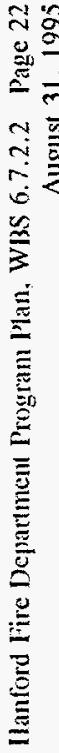




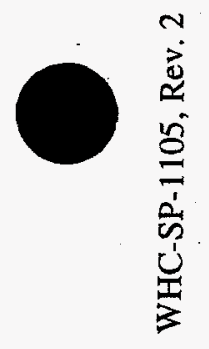

(1)

킁

త్ర

n

(1)

$\Xi$

이

0

$\frac{\pi}{0}$

$\Omega$

m

을

0

थ

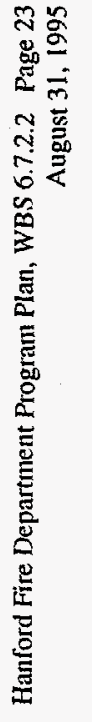




\begin{tabular}{|c|c|c|c|c|}
\hline \multicolumn{3}{|c|}{ 2.B.1 Milestone List } & \multicolumn{2}{|l|}{$\begin{array}{l}\text { Westinghouse Hanford Company } \\
\text { Hanford Fire Department } \\
\text { Program Plan } \\
\text { SMS/WBS No. 6.7.2.2 }\end{array}$} \\
\hline \multicolumn{2}{|c|}{ Milestone } & \multirow{2}{*}{$\begin{array}{c}\text { WBS } \\
\text { Number }\end{array}$} & \multirow{2}{*}{ Milestone Description } & \multirow{2}{*}{ Due Date } \\
\hline Type & Number & & & \\
\hline DOE-RL & 96-HFD-001 & 6.7 .2 .2 .1 & Fire System Testing Completion & $09 / 30 / 96$ \\
\hline DOE-RL & 96-HFD-002 & 6.7 .2 .2 .2 & Fire System Preventive Maintenance Completion & $09 / 30 / 96$ \\
\hline DOE-RL & 96-HFD-003 & 6.7.2.2.1 & 3rd Party Assessment Completion & $05 / 15 / 96$ \\
\hline DOE-RL & 96-HFD-004 & 6.7 .2 .2 & SCBA Upgrades & $09 / 30 / 96$ \\
\hline DOE-RL & 96-HFD-005 & 6.7 .2 .2 & Bar code control of SCBA equipment & $09 / 30 / 96$ \\
\hline DOE-RL & 96-HFD-006 & 6.7 .2 .2 & Develop statistical process control based performance measurements & $05 / 15 / 96$ \\
\hline
\end{tabular}




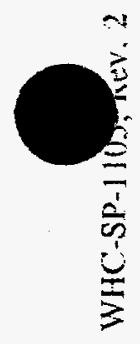

$\frac{1}{0}$

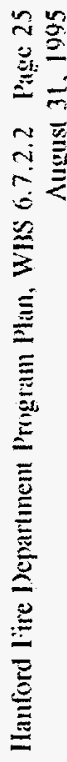

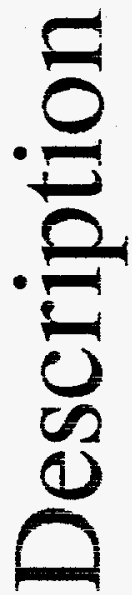

$\frac{0}{0}$ 


\section{Westinghouse Hanford Company \\ MILESTONE DESCRIPTION SHEET}

\begin{tabular}{|c|c|c|c|}
\hline \multicolumn{3}{|c|}{$\begin{array}{l}\text { Title: } \\
\text { Fire System Testing Completion }\end{array}$} & $\begin{aligned} \text { Date: } \\
10 / 01 / 95 \\
\end{aligned}$ \\
\hline \multicolumn{3}{|c|}{$\begin{array}{l}\text { Assigned To: } \\
\text { Hanford Fire Department, W. M. Knight }\end{array}$} & CIN: \\
\hline \multicolumn{3}{|c|}{$\begin{array}{l}\text { Program WBS Designator: } \\
6.7 .2 .2 .2\end{array}$} & $\begin{array}{r}\text { Due Date: } \\
09 / 30 / 96 \\
\end{array}$ \\
\hline \multicolumn{3}{|c|}{ Control Number: $96-$ HFD-001 } & Rev.: \\
\hline $\begin{array}{l}\text { MILESTONE TYPE: } \\
\square \text { DOE-HO } \\
\square \text { DOE-RL } \\
\square \text { CNTR }\end{array}$ & $\begin{array}{l}\text { DIVISION: } \\
\square \text { State } \\
\square \text { Federal } \\
\square \text { DOE } \\
\square \text { RCRA } \\
\square \text { TPA Number }\end{array}$ & $\begin{array}{l}\text { DELIVERABLE: } \\
\text { 囚 Report } \\
\square \text { Letter } \\
\square \text { Drawings } \\
\square \text { Other (specify) }\end{array}$ & $\begin{array}{l}\text { ADDRESS TO: } \\
\square \text { DOE-HQ } \\
\square \text { DOE-RL } \\
\square \text { Other (specify) }\end{array}$ \\
\hline
\end{tabular}

ilestone description:

Complete 100 percent of the fire system testing scheduled for the year

Description of what constitutes completion of this milestone:

Progress on completion of the commitment will be measured in the statistics provided to RL in the fire department's monthly report. Tests that cannot be performed due to circumstances beyond the control of the fire department will not be included in this milestone.

\section{st Account Manager}

\section{Date}

Program/Project Manager

Date 


\section{Westinghouse Hanford Company MILESTONE DESCRIPTION SHEET}

itle:

Fire System Preventive Maintenance Completion

Date:

Assigned To:

Hanford Fire Department, E. Blankingship

Program WBS Designator:

6.7 .2 .2 .2

Control Number: $96-\mathrm{HFD}-002$

MILESTONE TYPE:
$\square$ DOE-HO
囚 DOE-RL
$\square$ CNTR

\begin{tabular}{|l|}
\hline DIVISION: \\
$\square$ State \\
$\square$ Federal \\
$\square$ DOE \\
$\square$ RCRA \\
$\square$ TPA Number \\
\\
\end{tabular}

\begin{tabular}{|l|}
\hline DELIVERABLE: \\
$\square$ Report \\
$\square$ Letter \\
$\square$ Drawings \\
$\square$ Other (specify) \\
\end{tabular}

CIN:

$10 / 01 / 95$

Due Date:

$09 / 30 / 96$

Rev.:

ilestone description:

Complete 85 percent of the preventive maintenance scheduled for performance

by HFD personnel for the year.

Description of what constitutes completion of this milestone:

Completion of 85 percent of scheduled preventive maintenance as measured in the statistics provide to $\mathrm{RL}$ in the fire department monthly operations

report. PMs that cannot be completed due to circumstances beyond the

control of the HFD will not be included in this milestone.

st Account Manager

Date

Program/Project Manager

Date

P. E. Good

D.E. 200

Program Element Manager

$8 / 20 / 95 \sin$

웅

D. E. Good

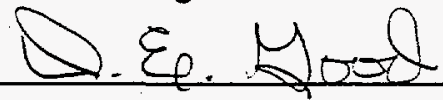

Date

DOE Monitor

Date

$8 / 30 / 95 /$ W. B. Scott 


\section{Westinghouse Hanford Company \\ MILESTONE DESCRIPTION SHEET}

\begin{tabular}{|c|c|c|c|}
\hline \multicolumn{3}{|c|}{$\begin{array}{l}\text { Title: } \\
\text { 3rd Party Assessment Completion }\end{array}$} & $\begin{array}{l}\text { Date: } \\
\qquad 10 / 01 / 95\end{array}$ \\
\hline \multicolumn{3}{|c|}{$\begin{array}{l}\text { Assigned To: } \\
\text { Hanford Fire Department, W. R. Hayes }\end{array}$} & CIN: \\
\hline \multicolumn{3}{|c|}{$\begin{array}{l}\text { Program WBS Designator: } \\
6.7 .2 .2 .1\end{array}$} & $\begin{array}{r}\text { Due Date: } \\
05 / 15 / 96 \\
\end{array}$ \\
\hline \multicolumn{3}{|c|}{ Control Number: $96-$ HFD-003 } & Rev.: \\
\hline $\begin{array}{l}\text { MILESTONE TYPE: } \\
\square \text { DOE-HQ } \\
\text { 囚 DOE-RL } \\
\square \text { CNTR }\end{array}$ & $\begin{array}{l}\text { DIVISION: } \\
\square \text { State } \\
\square \text { Federal } \\
\text { XDOE } \\
\square \text { RCRA } \\
\square \text { TPA Number }\end{array}$ & $\begin{array}{l}\text { DELIVERABLE: } \\
\text { 冈 Report } \\
\square \text { Letter } \\
\square \text { Drawings } \\
\square \text { Other (specify) }\end{array}$ & $\begin{array}{l}\text { ADDRESS TO: } \\
\square \text { DOE-HO } \\
\square \text { DOE-RL } \\
\square \text { Other (specify) }\end{array}$ \\
\hline
\end{tabular}

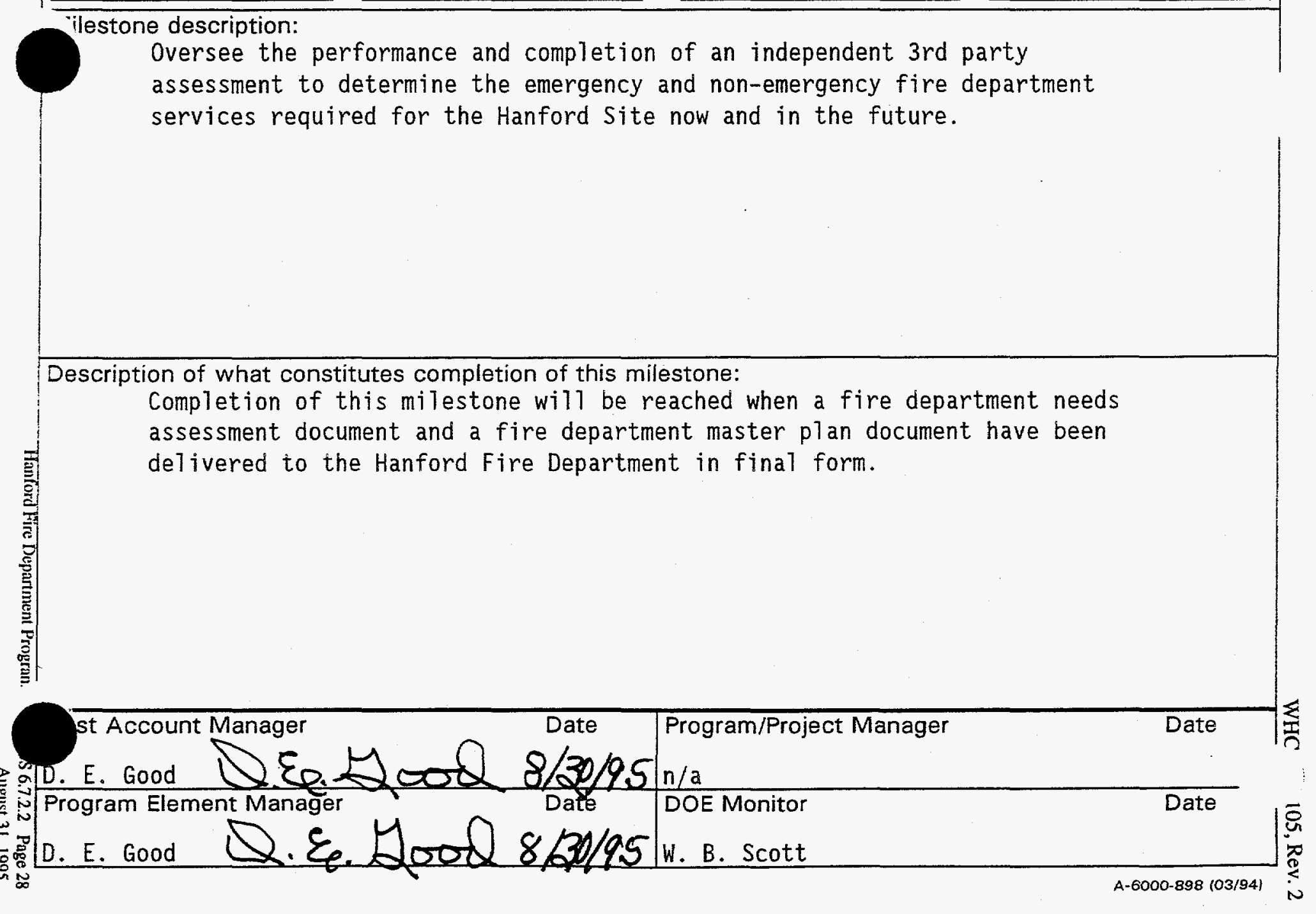




\section{Westinghouse Hanford Company MILESTONE DESCRIPTION SHEET}

\begin{tabular}{|c|c|c|c|}
\hline $\begin{array}{l}\text { Title: } \\
\text { SCBA Upgrades }\end{array}$ & & & \begin{tabular}{|r|} 
Date: \\
$10 / 01 / 95$ \\
\end{tabular} \\
\hline $\begin{array}{l}\text { Assigned To: } \\
\text { Hanford Fire Depar }\end{array}$ & W. R. Hayes & & CIN: \\
\hline $\begin{array}{l}\text { Program WBS Designa } \\
6.7 .2 .2 .1\end{array}$ & (2) & & $\begin{array}{r}\text { Due Date: } \\
09 / 30 / 96 \\
\end{array}$ \\
\hline Control Number: $96-\mathrm{H}$ & & & Rev.: \\
\hline $\begin{array}{l}\text { MILESTONE TYPE: } \\
\square \text { DOE-HO } \\
\square \text { DOE-RL } \\
\square \text { CNTR }\end{array}$ & $\begin{array}{l}\text { DIVISION: } \\
\square \text { State } \\
\square \text { Federal } \\
\text { 区 DOE } \\
\square \text { RCRA } \\
\square \text { TPA Number }\end{array}$ & $\begin{array}{l}\text { DELIVERABLE: } \\
\text { 囚 Report } \\
\square \text { Letter } \\
\square \text { Drawings } \\
\square \text { Other (specify) }\end{array}$ & $\begin{array}{l}\text { ADDRESS TO: } \\
\square \text { DOE-HO } \\
\square \text { DOE-RL } \\
\square \text { Other (specify) }\end{array}$ \\
\hline
\end{tabular}

\section{ilestone description:}

Modify or replace equipment as necessary to assure that 75 percent of the firefighting SCBA equipment is in compliance with NFPA 1981 revision of 1994.

Description of what constitutes completion of this milestone:

Purchase new HFD SCBA equipment and/or modify existing equipment to meet the requirements of NFPA 1981. Report completion of 75 percent or higher to $R L$. 


\section{Westinghouse Hanford Company MILESTONE DESCRIPTION SHEET}

Title:

Bar Code Control of SCBA Equipment

Assigned To:

Hanford Fire Department, W. M. Knight

Program WBS Designator:

Date:

$10 / 01 / 95$

CIN:

6.7 .2 .2

Control Number: $96-H F D-005$

MILESTONE TYPE:

$\square$ DOE-HO

冈 DOE-RL

$\square$ CNTR

\begin{tabular}{|l|}
\hline DIVISION: \\
$\square$ State \\
$\square$ Federal \\
冈DOE \\
$\square$ RCRA \\
$\square$ TPA Number \\
\end{tabular}

DELIVERABLE:
冈 Report
$\square$ Letter
$\square$ Drawings
$\square$ Other (specify)

Due Date:

$09 / 30 / 96$

Rev.:

ADDRESS TO:

$\square$ DOE-HQ

$\triangle$ DOE-RL

$\square$ Other (specify)

\section{Vilestone description:}

Implement a bar coding based equipment tracking system for HFD-owned SCBA equipment.

Description of what constitutes completion of this milestone:

Completion will be identified through an accurate tracking system of HFD-owned SCBA equipment, using a bar-coding based system and as reported in

the fire department's monthiy operations report to RL.

st Account Manager 


\section{Westinghouse Hanford Company MILESTONE DESCRIPTION SHEET}

Title:

Develop statistical process control based performance measurements

Assigned To:

Hanford Fire Department, D. E. Good

Program WBS Designator:

Due Date:

6.7 .2 .2

Control Number: 96 -HFD-006

MILESTONE TYPE:

$\square$ DOE-HQ

X DOE-RL

$\square$ CNTR

\begin{tabular}{|c|c|c|}
\hline $\begin{array}{l}\text { MILESTONE TYPE: } \\
\square \text { DOE-HO } \\
\square \text { DOE-RL } \\
\square \text { CNTR }\end{array}$ & $\begin{array}{l}\text { DIVISION: } \\
\square \text { State } \\
\square \text { Federal } \\
\text { XDOE } \\
\square \text { RCRA } \\
\square \text { TPA Number }\end{array}$ & $\begin{array}{l}\text { DELIVERABLE: } \\
\text { ख Report } \\
\square \text { Letter } \\
\square \text { Drawings } \\
\square \text { Other (specify) }\end{array}$ \\
\hline
\end{tabular}

\begin{tabular}{|c|c|c|}
\hline $\begin{array}{l}\text { MILESTONE TYPE: } \\
\square \text { DOE-HO } \\
\square \text { DOE-RL } \\
\square \text { CNTR }\end{array}$ & $\begin{array}{l}\text { DIVISION: } \\
\square \text { State } \\
\square \text { Federal } \\
\text { 囚 DOE } \\
\square \text { RCRA } \\
\square \text { TPA Number }\end{array}$ & $\begin{array}{l}\text { DELIVERABLE: } \\
\square \text { Report } \\
\square \text { Letter } \\
\square \text { Drawings } \\
\square \text { Other (specify) }\end{array}$ \\
\hline
\end{tabular}

$05 / 15 / 96$

Rev.:

$10 / 01 / 95$

vilestone description:

Finalize the delivery of performance measurements for identified fire department activities using proven statistical process control methodology based on Deming's Theory of Variation.

Description of what constitutes completion of this milestone:

Inclusion of identified performance measurements in the fire department's monthly operations report to RL. 


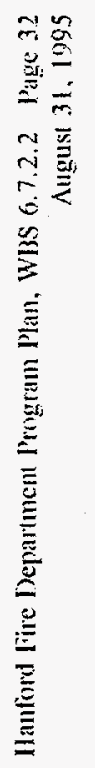

0
0
0
0
0
0
0
0 


\begin{tabular}{|c|c|c|c|c|c|c|c|c|c|}
\hline $\begin{array}{l}\text { Work } \\
\text { Breakdown } \\
\text { Structure } \\
\text { Dictionary }\end{array}$ & \multicolumn{6}{|c|}{$\begin{array}{c}\text { Westinghouse Hanford ( pany } \\
\text { HANFORD FIRE DEPARTMENT } \\
\text { Part I - Summary } \\
\text { (Dollars in 000's) }\end{array}$} & \multicolumn{3}{|c|}{$\begin{array}{l}\text { FY } 1996 \\
\text { Indirect } \\
\text { Program Plan } \\
\text { Rev. \# } 0 \\
\text { 31-Aug-95 } \\
\end{array}$} \\
\hline $\begin{array}{c}\text { Cost Account Number } \\
1 \text { J8R00 } \\
\end{array}$ & \multicolumn{6}{|c|}{ HANFORD FIRE DEPARTMENT } & \multicolumn{3}{|c|}{$\begin{array}{l}\text { Proposed Rate: } \\
\text { (Rated Service Pool Onlv) }\end{array}$} \\
\hline $\begin{array}{r}\text { SMS WBS Number } \\
6.7 .2 .2 \\
\end{array}$ & \multicolumn{6}{|c|}{ HANFORD FIRE DEPARTMENT OVERHEAD } & \multicolumn{3}{|c|}{$\begin{array}{ll}\text { G\&A } & \text { Funding Source: } \\
\end{array}$} \\
\hline RL SMS Program Manger & \multicolumn{6}{|c|}{ W.B. SCOTT } & \multicolumn{3}{|l|}{ sws } \\
\hline Cost Account Manager & \multirow{2}{*}{\multicolumn{6}{|c|}{$\begin{array}{l}\text { D.E. GOOD } \\
\text { D.E. GOOD }\end{array}$}} & OST & & \\
\hline WHC SMS Program Manager & & & & & & & $\mathrm{DOH}$ & \multicolumn{2}{|c|}{$X X X X X X X X X X X X$} \\
\hline Financial Manager & \multicolumn{6}{|c|}{ D.L. BORDERS } & \multicolumn{3}{|l|}{ MGT PRO } \\
\hline Responsible Analyst & \multicolumn{6}{|c|}{ O. JOHNSON } & \multirow{2}{*}{\multicolumn{3}{|c|}{$\begin{array}{l}\text { POOL } \\
\text { FY } 1996 \text { Baseline } \\
\text { Full-TIme Equivalents (FTEs) }\end{array}$}} \\
\hline 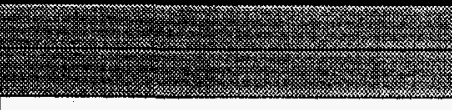 & \multicolumn{3}{|c|}{$\begin{array}{c}\text { FY } 1996 \text { Approved Funding } \\
\text { Full-Time Equivalents (FTEs) }\end{array}$} & \multicolumn{3}{|c|}{$\begin{array}{l}\text { FY } 1996 \text { Unfunded } \\
\text { Full-Time Equivalents (FTEs) }\end{array}$} & & & \\
\hline TYPE OF FTE & Exempt & Non-Exempt & Bargaining & Exempt & Non-Exempt & Bargaining & Exempt & \begin{tabular}{|l|} 
Non-Exempt \\
\end{tabular} & Bargaining \\
\hline Organizational & 2.0 & 1.0 & 0.0 & 0.0 & 0.0 & 0.0 & 2.0 & \begin{tabular}{r|}
1.0 \\
\end{tabular} & 0.0 \\
\hline Support & 0.5 & 0.0 & 0.0 & 0.0 & 0.0 & 0.0 & 0.5 & 0.0 & 0.0 \\
\hline TOTAL FTEs & 2.5 & 1.0 & 0.0 & 0.0 & 0.0 & 0.0 & 2.5 & 1.0 & 0.0 \\
\hline COST ELEMENTS & \multicolumn{3}{|c|}{ FY 1996 Approved Funding Budget } & \multicolumn{3}{|c|}{ FY 1996 Unfunded Budget } & \multicolumn{3}{|c|}{ FY 1996 Baseline Budget } \\
\hline . Labor - Regular & & & $\$ 210$ & & & & & & $\$ 210$ \\
\hline . Labor - Overtime & & & $\$ 0$ & & & & & & $\$ 0$ \\
\hline 0 Total Labor & & & $\$ 210$ & & & $\$ 0$ & & & $\$ 210$ \\
\hline 1 Materlais & & & $\$ 0$ & & & & & & $\$ 0$ \\
\hline 2 Purchased Services & & & $\$ 8$ & & & & & & $\$ 8$ \\
\hline 3 Other Hanford & & & $\$ 1$ & & & & & & $\$ 1$ \\
\hline Subtotal orghinated Costs & & & 52.19 & & & 50 & & & 2819 \\
\hline 4 Site Services & & & $\$ 101$ & & & & & & $\$ 101$ \\
\hline 5 Internal Charges & & & $\$ 67$ & & & & & & $\$ 67$ \\
\hline 6 IRM Support & & & $\$ 13$ & & & & & & $\$ 13$ \\
\hline 7 Overheads & & & $\$ 12$ & & & & & & $\$ 12$ \\
\hline 8 Revenue & & & & & & & & & $\$ 0$ \\
\hline TOTAL DOLLARS & & & $\$ 412$ & & & $\$ 0$ & & & $\$ 412$ \\
\hline $\begin{array}{l}\text { SIGNATURES } \\
\text { Financial Analyst } \\
\text { CAM: }\end{array}$ & & & Date: $2 / 25 / 95$ & & BASELINE API & ROVAL & & & \\
\hline
\end{tabular}




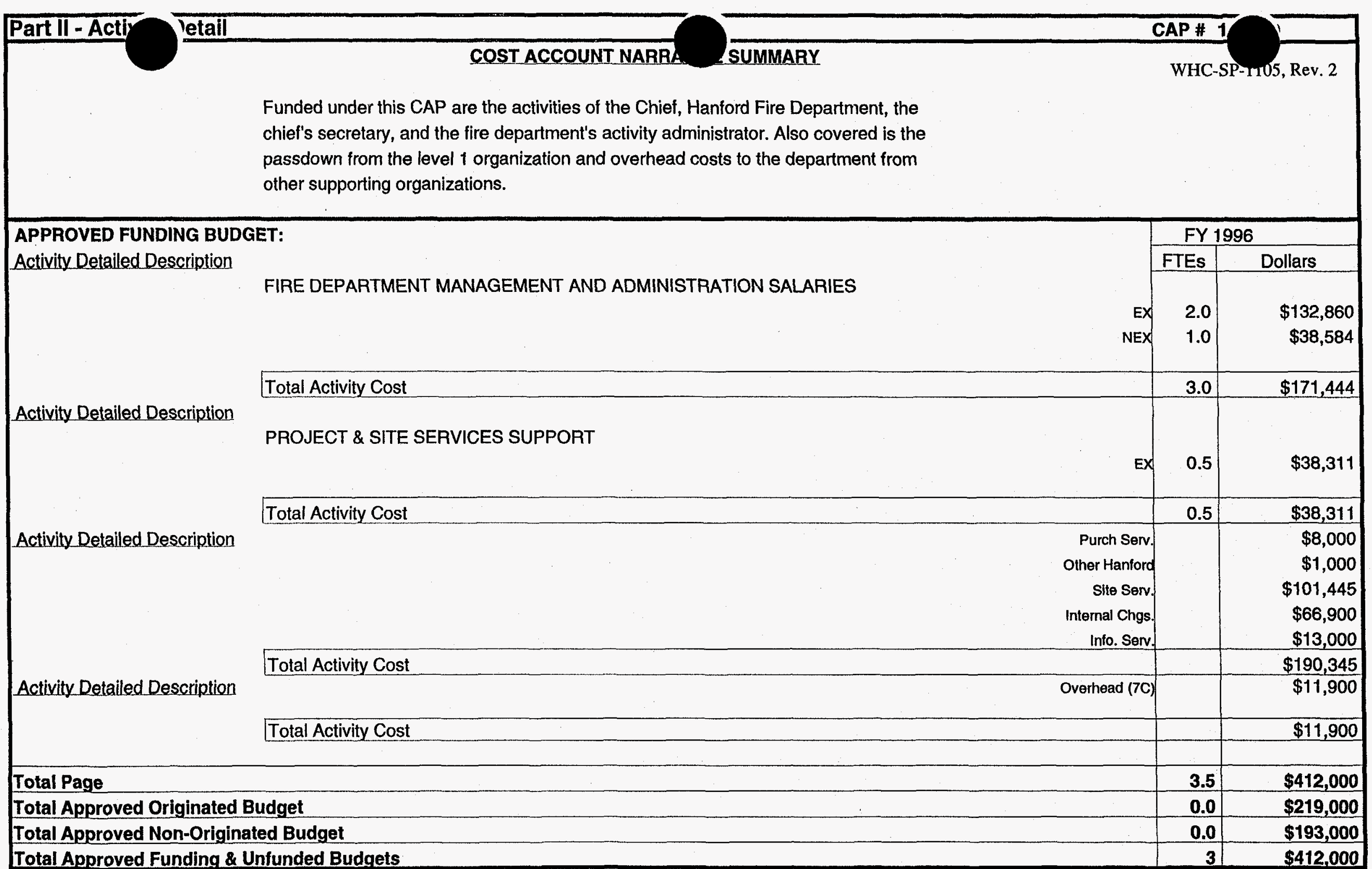




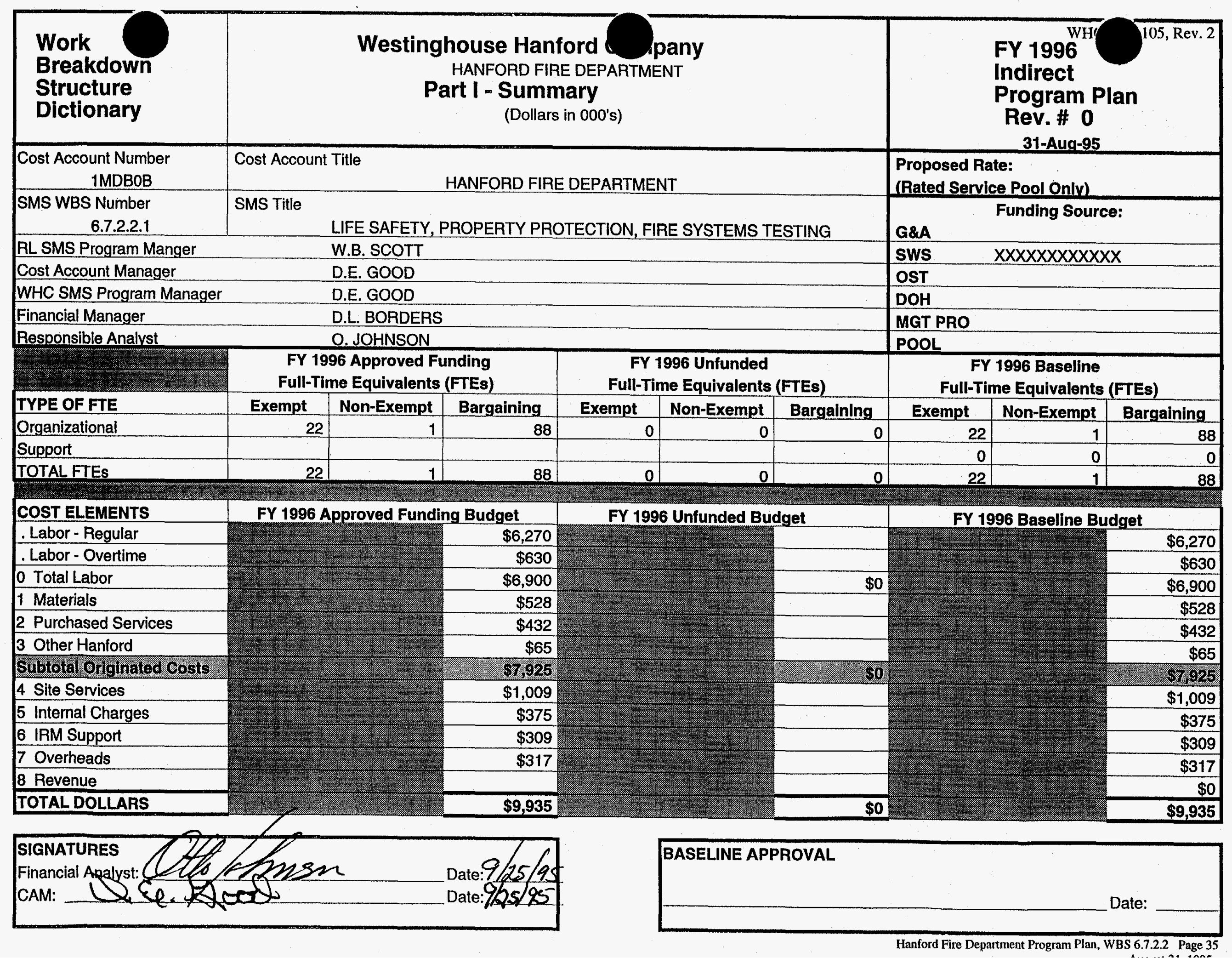




\section{APPROVED FUNDING BUDGET:}

Activity Detailed Description

ACTIVITY \#1 - Fundamental Fire Suppression (24 hour) (200 \& 300 Areas)

This level of service provides around-the-clock, fundamental fire suppression, building tours and inspections, and prefire planning. The individuals assigned to emergency response crews are cross-trained to perform multiple suppression duties -- structural, wildland, and radiological -and interact with the other fire station to meet minimum staffing requirements.

Activity Delailed Description

\section{Total Activity Cost}

ACTIVITY \#2 - 24-Hour Emergency Medical (200 Areas)

This ambulance would be staffed around the clock with advanced life support (ALS) capabilities. Ambulances are licensed under the Washington State Department of health and attendants are trained to meet the bloodborne pathogens and communicable disease prevention requirements under OSHA 29CFR 1910.1030. Paramedics are cross-certified as firefighters but would not be available to augment minimum staffing requirements. At this level there is no absence relief or backup medical response.

Activity Detailed Description

\section{Total Activity Cost}

ACTIVITY \#3 - Supplementary Fire Suppression (24 hour) (100 \& 400 Areas) This level of service would allow complete fire suppression capabilities, including hazardous materials and specialized rescue responses, building tours and inspections, fire watch, emergency prefire planning, and fire hydrant testing. The individuals assigned to emergency response crews are cross-trained to perform multiple emergency tasks and interact with other fire stations to meet minimum staffing requirements.

Total Activity Cost

ACTIVITY \#4 - Dayshift Emergency medical (100, 300, \& 400 Areas)

Activity Detailed Description This level of service would provide dayshift, Monday through Friday, emergency medical response capability in the 100,300, and 400 Areas during peak occupancy and operational periods.

\section{Total Activity Cost}

Activity Detailed Description

\section{ACTIVITY \#5 - Administrative, Enforcement, \& Support Services}

This level of service provides operational control and fire ground safety, administration, clerical, and code enforcement through the fire marshal's office. Statistical reporting of fire protection system performance; emergency incident reports; ignitable and reactive waste inspections; issuance of permits for controlled burning, occupancy, and demolition; and fire investigations are all provided within this task. Included in this task for FY 1996 is $\$ 307 K$ to fund completion of a 3rd party assessment of HFD services. This assessment was requested by RL, was a FY 1995 milestone, and is expected to be a FY 1996 milestone. Also 'included in this activity is funding for an administrative assistant position, which was overhead funded in FY 1995.

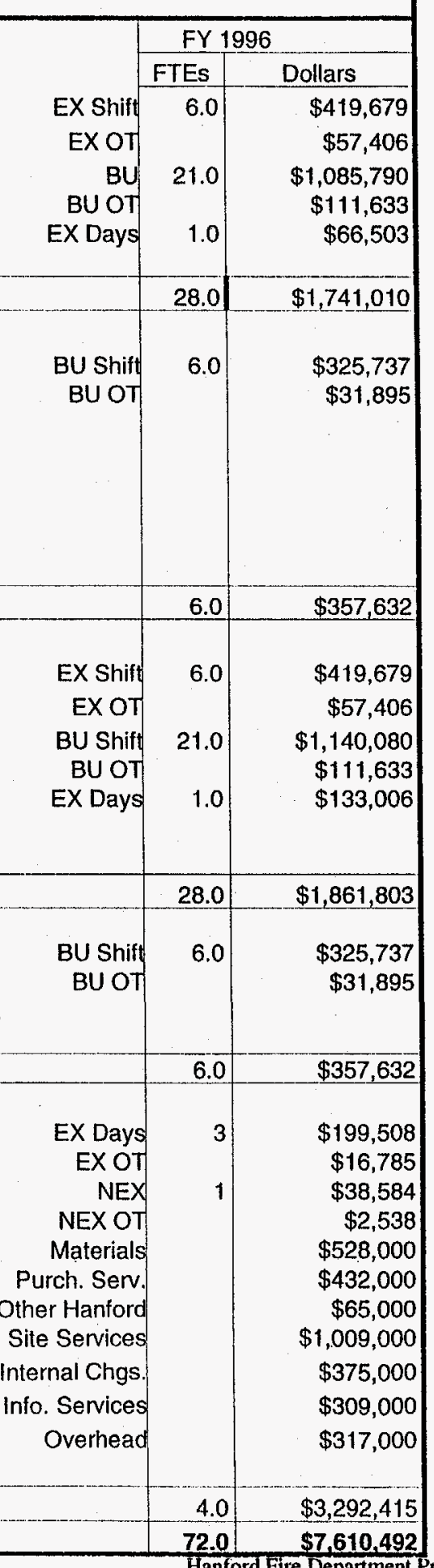




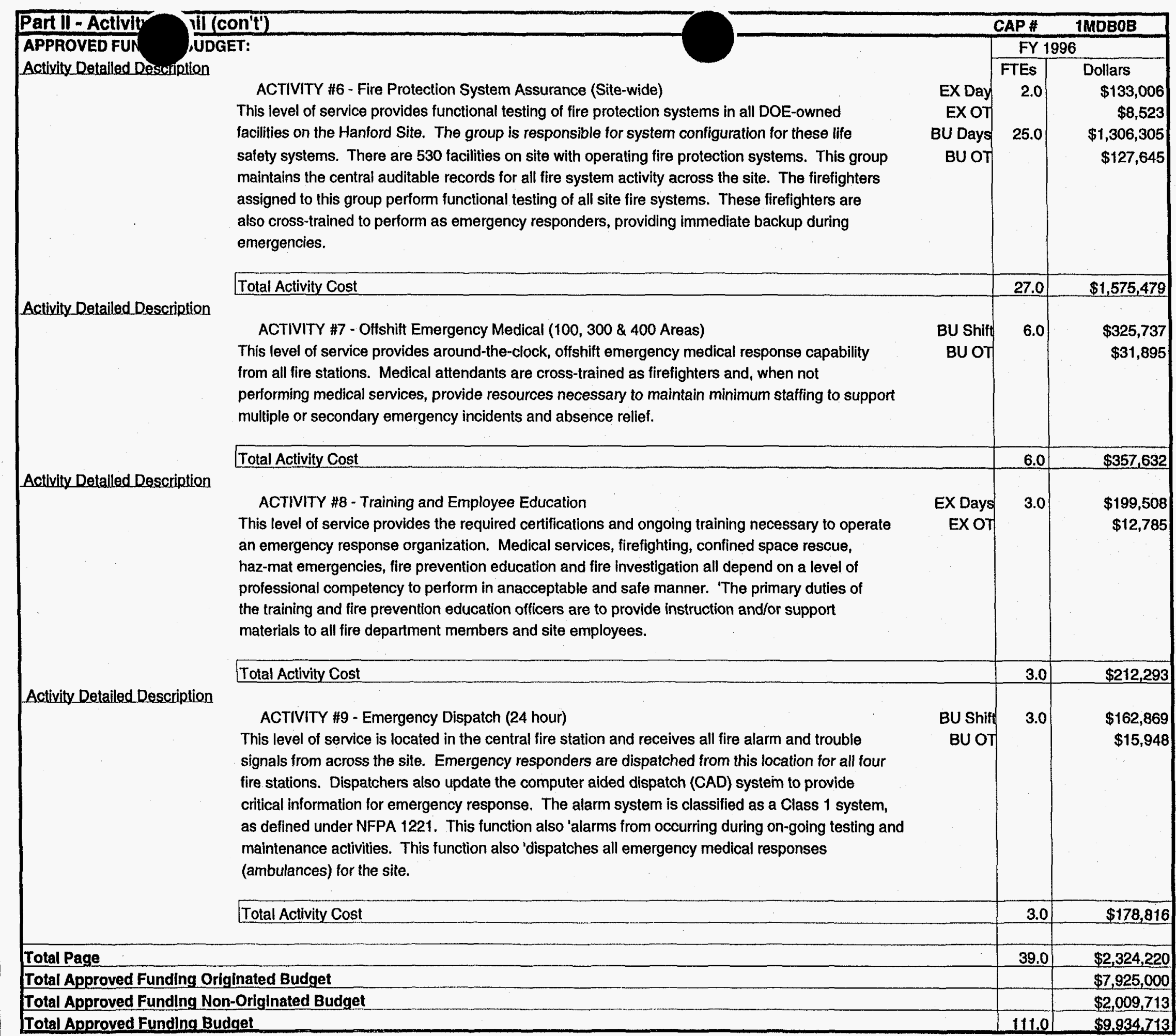
safety systems. There are 530 facilities on site with operating fire protection systems. This group emergencies.

\section{Total Activity Cost}

ACTIVITY \#8 - Training and Employee Education

Hanford Fire Department Program Plan, WBS 67.2.2 Page 37 


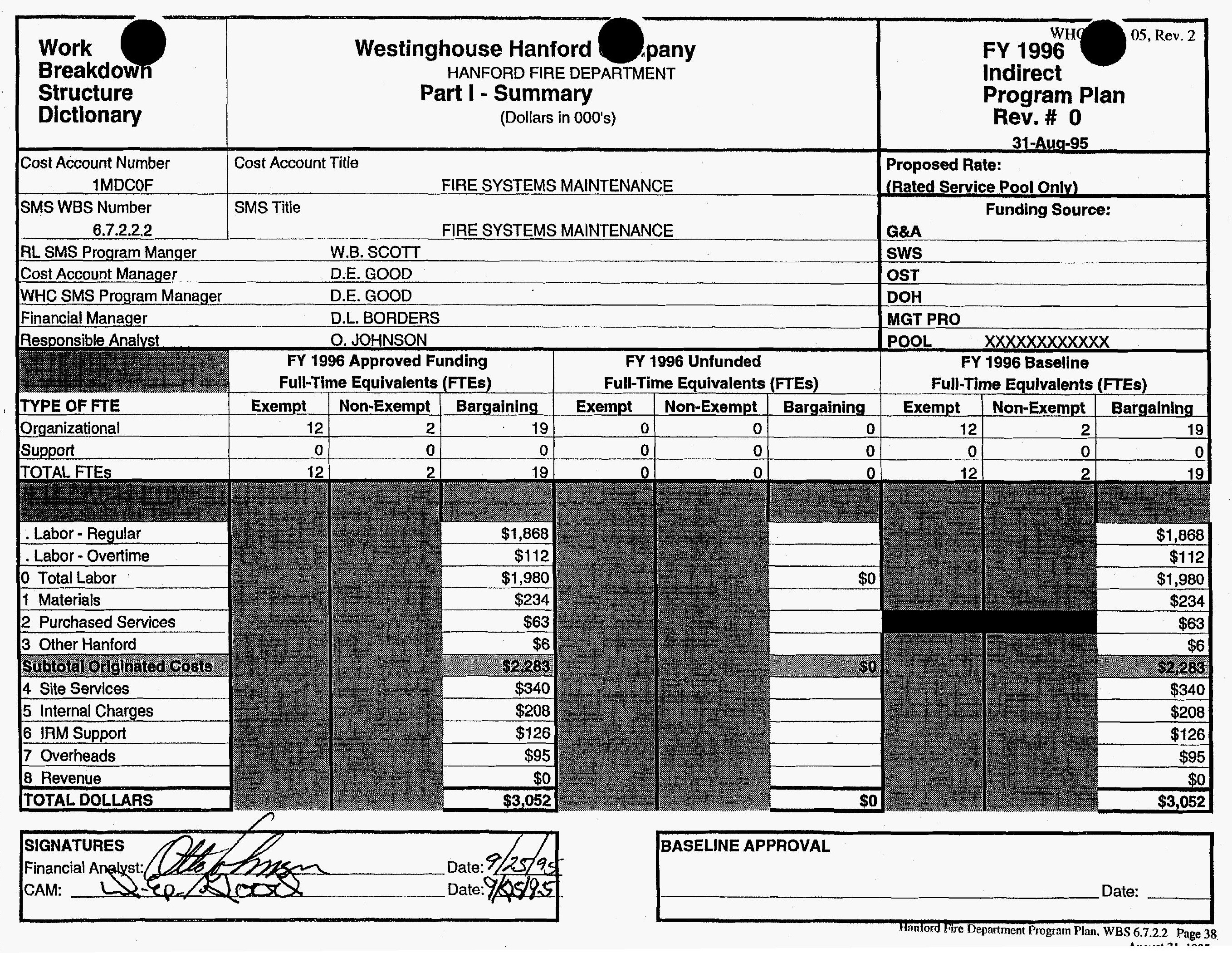


Fire System Maintenance: Fire alarm, fire suppression, and fire water distribution maintenance service is provided for all Westinghouse Hanford Company

(WHC) facilities, for those ICF Kaiser facilities that were previously managed by WHC, Bechtel, the Bonneville Power Administration Ashe Substation,

and the 313 Building operated by Kaiser Aluminum. These services include: functional testing of fire system components, systems and devices in 530 Hanford buildings and facilities; and corrective and preventive maintenance of approximately 19,238 fire alarm and suppression system devices

\section{APPROVED FUNDING BUDGET:}

Activity Detailed Description

MFMAD - This activity involves the administrative, management, procurement, and procedure development lasks performed by the fire system maintenance organization. Included are secretarial costs, material coordinator costs, and all non-labor related costs for the organization.

Activity Detailed Description

Total Activity Cost

MFMPM - This activity involves the maintenance of electrical fire systems in facilities located nor of the Wye Barricade.

\section{Total Activity Cost}

Activity Detailed Description

MFMRP - This activity involves the maintenance of fire systems (mechanical and electrical) locat in facilities south of the Wye Barricade. Included in this activity is the engineering and planning/ scheduling support for these tasks.

Total Activity Cost

Activity Detailed Description

MFMTR - This activity involves the maintenance of mechanical fire systems, such as sprinklers hydrants, and ground gate valves, north of the Wye Barricade. Included in this activity is the engineering and planning/scheduling support for these tasks.

Total Activity Cost

\section{Page Total}

Total Approved Funding Originated Budget

Total Approved Funding Non-Originated Budget

Total Approved Funding Budget

\section{FY 1996}

FTES Dollars

EX Days

NEX Days

NEXOT

BU Days

Materials

Purch. Serv

Other Hanford

Site Services Internal Chgs.

Info. Services

Overhead

5 \$332,514

$2 \quad \$ 77,168$

$3 \quad \begin{array}{r}\$ 1,269 \\ \$ 156,757\end{array}$

$\$ 234,000$

$\$ 63,000$

$\$ 6,000$

$\$ 340,000$

$\$ 208,000$

$\$ 126,000$

$\$ 95,000$

$\$ 1,639,707$

$\$ 199,508$

$\$ 1,474$

$\$ 313,513$

EX OT

BU Days

BU OT

$\$ 40,057$

$\$ 554,553$

$\$ 66,503$

\begin{tabular}{rr|r} 
EX OT & & $\$ 478$ \\
BU Days & 4 & $\$ 209,009$
\end{tabular}

\begin{tabular}{rr|r} 
EX OT & & $\$ 478$ \\
BU Days & 4 & $\$ 209,009$
\end{tabular}

BU OT

$\$ 302,695$

5

3

$\$ 199,508$

$\$ 1,474$

EXOT

BU Days

BU OT

6

$\$ 313,513$

$\$ 40,057$

$9 \quad \$ 554,553$

$33 \$ 3,051,507$

$\$ 2,283,000$

$\$ 785,507$

$\$ 3.051,507$ 


\begin{tabular}{|l|c|c|}
\hline & Westinghouse Hanford Company \\
2.C.1 & Hanford Fire Department & FY 1996 \\
Cost Baseline by Program Element & Program Plan & Site Support Program Plan \\
\hline
\end{tabular}

\section{FY 1995 Cost Baseline}

(\$s in 000s)

\begin{tabular}{|l|l|c|}
\hline \multicolumn{1}{|c|}{ WBS No. } & \multicolumn{1}{|c|}{ Title } & Total \$s \\
\hline 6.7 .2 .2 .1 & Life Safety, Property Protection, and Fire Systems Testing & $\$ 9,342.0$ \\
\hline 6.7 .2 .2 .2 & Fire Systems Maintenance & $\$ 3,257.0$ \\
\hline
\end{tabular}

Excludes company adders (G\&A and CSP/Oversight)

\section{FY 1996 Cost Baseline}

( $\$$ s in 000 s)

\begin{tabular}{|c|c|c|}
\hline WBS No. & Title & Total \$s \\
\hline 6.7.2.2.1 & Life Safety, Property Protection, and Fire Systems Testing & $\$ 9,935.0$ \\
\hline 6.7 .2 .2 .2 & Fire Systems Maintenance & $\$ 3,052.0$ \\
\hline & & $\$ 12,987.0$ \\
\hline
\end{tabular}

Excludes company adders (G\&A and CSP/Oversight) 
2.C.1

Cost Baseline by Program Element (cont.)
Westinghouse Hanford Company

Hanford Fire Department

Program Plan

SMS/WBS No. 6.7.2.2
FY 1996

Site Support Program Plan

\section{FY 1997 Cost Baseline}

(\$s in 000s)

\begin{tabular}{|c|c|c|}
\hline WBS No. & Title & Total \$s \\
\hline 6.7 .2 .2 .1 & Life Safety, Property Protection, and Fire Systems Testing & $\$ 9,929.2$ \\
\hline 6.7 .2 .2 .2 & Fire Systems Maintenance & $\$ 3,143.6$ \\
\hline & & $\$ 13,072.8$ \\
\hline
\end{tabular}

Excludes company adders (G\&A and CSP/Oversight)

\section{FY 1998 Cost Baseline}

(\$s in 000s)

\begin{tabular}{|l|l|c|}
\hline \multicolumn{1}{|c|}{ WBS No. } & \multicolumn{1}{|c|}{ Title } & Total \$s \\
\hline 6.7 .2 .2 .1 & Life Safety, Property Protection, and Fire Systems Testing & \$10,227.1 \\
\hline 6.7 .2 .2 .2 & Fire Systems Maintenance & $\$ 3,237.9$ \\
\hline
\end{tabular}

Excludes company adders (G\&A and CSP/Oversight) 


\begin{tabular}{|l|c|c|}
\hline & Westinghouse Hanford Company & FY 1996 \\
2.C.1.1 & Hanford Fire Department & Site Support Program Plan \\
Cost Baseline by Activity & Program Plan & \\
\hline
\end{tabular}

\section{FY 1995 Cost Baseline}

(Dollars in Thousands)

\begin{tabular}{|c|c|c|}
\hline Activity & Description & Total \$s \\
\hline 6.7 .2 .2 .1 & $\begin{array}{l}\text { Life safety and property protection including fire suppression, rescue, emergency medical response, HAZMAT response, fire } \\
\text { prevention, SCBA servicing and repair, and functional testing of fire alarm and suppression systems. }\end{array}$ & $\$ 9,342,0$ \\
\hline 6.7 .2 .2 .2 & $\begin{array}{l}\text { Preventive and repair maintenance of all fire systems installed in most ICF Kaiser and all WHC and Bechtel buildings and facilities } \\
\text { located on site. }\end{array}$ & $\$ 3,257.0$ \\
\hline \multicolumn{2}{|c|}{ [Excludes company adders (G\&A and CSP/Oversight)] } & $\$ 12,599.0$ \\
\hline
\end{tabular}

\section{FY 1996 Cost Baseline}

(Dollars in Thousands)

\begin{tabular}{|c|c|c|}
\hline 6.7 .2 .2 .1 & $\begin{array}{l}\text { Life safety and property protection including fire suppression, rescue, emergency medical response, hazardous materials response, } \\
\text { fire systems testing, fire prevention, and SCBA servicing and repair. Includes 1) } \$ 295.0 \mathrm{~K} \text { funding to comlete a DOE-RL requested } \\
\text { 3rd party assessment of fire protection services at Hanford. }\end{array}$ & $\$ 9,935.0$ \\
\hline 6.7 .2 .2 .1 & Fire systems preventive maintenance and repair. & $\$ 3,052.0$ \\
\hline \multicolumn{2}{|c|}{ [Excludes company adders (G\&A and CSP/Oversight)] } & $\$ 12,987.0$ \\
\hline
\end{tabular}




\begin{tabular}{|l|c|c|}
\hline & Westinghouse Hanford Company \\
$\begin{array}{l}\text { 2.c.1.1 } \\
\text { Cost Baseline by Activity } \\
\text { (cont.) }\end{array}$ & Hanford Fire Department \\
& Program Plan & FY 1996 \\
SMS/WBS No. 6.7.2.2 & Site Support Program Plan \\
\hline
\end{tabular}

\section{FY 1997 Cost Baseline}

(Dollars in Thousands)

\begin{tabular}{|c|c|c|}
\hline Activity & Description & Total \$s \\
\hline 6.7 .2 .2 .1 & $\begin{array}{l}\text { Life safety and property protection including fire suppression, rescue, emergency medical response, fire systems testing, } \\
\text { hazardous materials response, and SCBA service and repair. Includes } 3.0 \% \text { escalation. }\end{array}$ & $\$ 9,929.2$ \\
\hline 6.7 .2 .2 .2 & Fire system assurance and maintenance of fire systems. Reflects $3.0 \%$ escalation. & $\$ 3,143.6$ \\
\hline \multicolumn{2}{|c|}{ [Excludes company adders (G\&A and CSP/Oversight)] } & $\$ 13,072.8$ \\
\hline
\end{tabular}

\section{FY 1998 Cost Baseline}

(Dollars in Thousands)

\begin{tabular}{|l|l|c|}
\hline 6.7 .2 .2 .1 & $\begin{array}{l}\text { Life safety and property protection including fire suppression, rescue, emergency medical response, fire systems testing, } \\
\text { hazmat response, and SCBA service and repair. Includes 3.0\% escalation. }\end{array}$ & \$10,227.1 \\
\hline 6.7 .2 .2 .2 & Fire system assurance including testing and maintenance of fire systems. Reflects $2.9 \%$ escalation. & $\$ 3,237.9$ \\
\hline [Excludes company adders (G\&A and CSP/Oversight) & FY 1998 Total for (SMS/WBS No) & \$13,465.0 \\
\hline
\end{tabular}




\begin{tabular}{|c|c|c|c|c|c|c|c|}
\hline \multicolumn{2}{|c|}{$\begin{array}{l}2 . \text { C.1.2 } \\
\text { Cost Baseline by Funding Source }\end{array}$} & \multicolumn{4}{|c|}{$\begin{array}{c}\text { Westinghouse Hanford Company } \\
\text { Hanford Fire Department } \\
\text { Program Plan } \\
\text { SMS/WBS No. 6.7.2.2 }\end{array}$} & \multicolumn{2}{|c|}{$\begin{array}{c}\text { FY } 1996 \\
\text { Site Support Program Plan }\end{array}$} \\
\hline WBS \# & Title & $\begin{array}{l}\text { Dept. } \\
\text { OH }\end{array}$ & CSP/Oversight & SLP & $\mathbf{G} \& \mathbf{A}$ & Direct $\$$ & TOTAL \$s \\
\hline \multicolumn{8}{|c|}{$\begin{array}{l}\text { FY } 1995 \text { Cost Baseline } \\
\text { (Dollars in Thousands) }\end{array}$} \\
\hline 6.7 .2 .2 & Functional Overhead & $\$ 352.8$ & & & & & \\
\hline 6.7 .2 .2 .1 & Emergency Services & & $\$ 9,130.6$ & & & & \\
\hline 6.7 .2 .2 .2 & Fire Systems Maintenance & & & $\$ 3,115.6$ & & & \\
\hline & TOTALS & $\$ 352.8$ & $\$ 9,130.6$ & $\$ 3,115.6$ & & & $\$ 12,599.0$ \\
\hline \multicolumn{8}{|c|}{$\begin{array}{l}\text { FY } 1996 \text { Cost Baseline } \\
\text { (Dollars in Thousands) }\end{array}$} \\
\hline 6.7 .2 .2 & Functional Overhead & $\$ 412.0$ & & & & & \\
\hline 6.7 .2 .2 .1 & $\begin{array}{l}\text { Emergency Services and Fire } \\
\text { Systems Testing }\end{array}$ & & $\$ 9,618.0$ & & & & \\
\hline 6.7 .2 .2 .2 & Fire Systems Maintenance & & & $\$ 2,957.0$ & & & \\
\hline & TO'TALS & $\$ 412.0$ & $\$ 9,618.0$ & $\$ 2,957.0$ & & & $\$ 12,987.0$ \\
\hline
\end{tabular}




\begin{tabular}{|c|c|c|c|c|c|c|c|}
\hline \multicolumn{2}{|c|}{$\begin{array}{l}\text { 2.C.1.2 } \\
\text { Cost Baseline by Funding Source }\end{array}$} & \multicolumn{4}{|c|}{$\begin{array}{l}\text { Westinghouse Hanford Company } \\
\text { Hanford Fire Department } \\
\text { Program Plan } \\
\text { SMS/WBS No. } 6.7 .2 .2\end{array}$} & \multicolumn{2}{|c|}{$\begin{array}{c}\text { FY } 1996 \\
\text { Site Support Program Plan }\end{array}$} \\
\hline WBS \# & Title & $\begin{array}{c}\text { Dept. } \\
\text { OH }\end{array}$ & CSP/Oversight & SLP & $\mathbf{G} \& \mathbf{A}$ & Direct \$ & TOTAL \$s \\
\hline
\end{tabular}

FY 1997 Cost Baseline

(Dollars in Thousands)

\begin{tabular}{|r|l|r|r|r|r|r|r||}
\hline 6.7 .2 .2 & Functional Overhead & $\$ 424.4$ & & & & & \\
\hline 6.7 .2 .2 .1 & $\begin{array}{l}\text { Emergency Services and Fire } \\
\text { Systems Testing }\end{array}$ & & $\$ 9,602.7$ & & & & \\
\hline 6.7 .2 .2 .2 & Fire Systems Maintenance & & & $\$ 3,045.7$ & & & \\
\hline & TOTALS & $\$ \mathbf{4 2 4 . 4}$ & $\mathbf{\$ 9 , 6 0 2 . 7}$ & $\mathbf{\$ 3 , 0 4 5 . 7}$ & & & $\$ 13,072.8$ \\
\hline
\end{tabular}

FY 1998 Cost Baseline

(Dollars in Thousands)

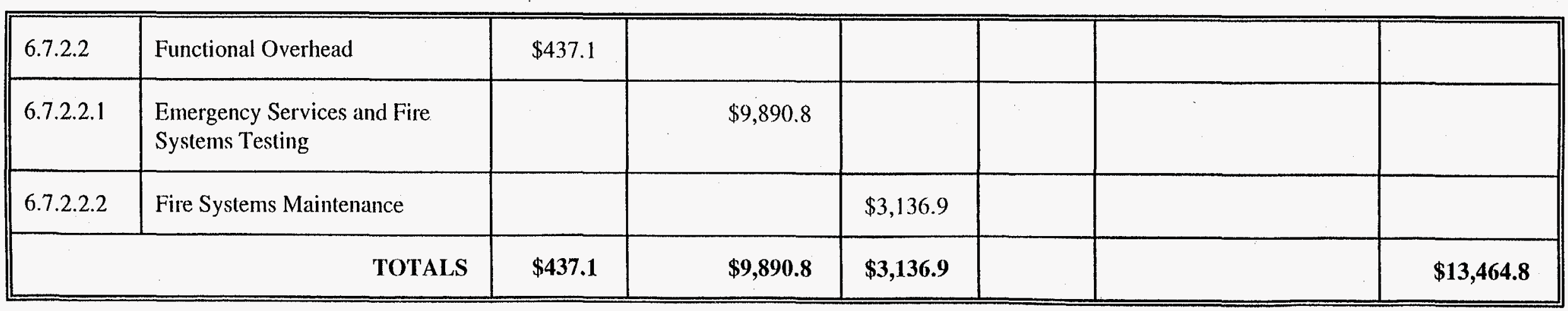




\begin{tabular}{|l|c|c|}
\hline 2.C.2 Cost Basis & $\begin{array}{c}\text { Westinghouse Hanford Company } \\
\text { Hanford Fire Department }\end{array}$ & $\begin{array}{c}\text { FY 1995 } \\
\text { Program Plan }\end{array}$ \\
& SMS/WBS No. 6.7.2.2 & \\
\hline
\end{tabular}

Cost Estimating Assumptions:

Costs are based on requirements as they exist today and do not include funds for future changes to requirement documents.

Estimating Methodology:

The estimate for the emergency services portion of the budget is based on an analysis of national code and DOE order requirements and the staffing and materials required to meet these. Customer organizations are assessed a percentage of this budget based upon the size of their budget compared to the total site budget.

The estimate for the maintenance activity costs is based upon the number and type of fire system equipment items in service and the annual time required to test and maintain them to current requirements. Costs to individual customer organizations are based upon the specific equipment installed in that customer's facilities and any special hazards related to the tasks. 


\section{HANFORD FIRE DEPARTMENT}

\section{C.3 FTEs}

WBS Number 6.7.2.2

WHC-SP-1105, Rev. 2

FY 1996 SSPP

\begin{tabular}{|c|c|c|c|c|c|c|c|c|}
\hline \multicolumn{4}{|l|}{ Planned Staffing (FTEs) } & \multicolumn{5}{|c|}{ NOTE: Job Family Only After 1997} \\
\hline JOB FAMULY & Cocs No: & & 2. & $2=2$ & 2 & $2=2$ & $2=2$ & 3 \\
\hline Job category & & 1996 & 1997 & 1998 & 1999 & 2000 & 2001 & 2002 \\
\hline MANAGERS & 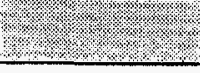 & 18 & $\sqrt{1.18} \cdot 18$ & 18 & $18=$ & 2.18 & 4.18. & 18 \\
\hline First line & M010 & 17 & 17 & 17 & 17 & 17 & 17 & 17 \\
\hline General/executive & M020 & 1 & 1 & 1 & 1 & 1 & 1 & 1 \\
\hline ENGINEERS & 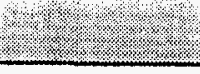 & $=9$ & 9.9 & 2.29 .97 & 9.2 & 2.9 .9$. & 2.9 & 9 \\
\hline Plant & E100 & 9 & 9 & 9 & 9 & 9 & 9 & 9 \\
\hline $\begin{array}{l}\text { ADMINIOTHER } \\
\text { PROFESSIONALS }\end{array}$ & & 16 & $\frac{16}{16}$ & (16. & 16 & 16 & 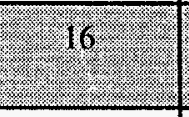 & (1) 16 \\
\hline Compliance inspectors & $\mathrm{P} 050$ & 2 & 2 & 2 & 2 & 2 & 2 & 2 \\
\hline Cost Est/planner/sch & $\mathrm{P} 070$ & 3 & 3 & 3 & 3 & 3 & 3 & 3 \\
\hline Physician Assis/Nurs & $\mathrm{P} 130$ & 9 & 9 & 9 & 9 & 9 & 9 & 9 \\
\hline Trainers & P150 & 2 & 2 & 2 & 2 & 2 & 2 & 2 \\
\hline GENADMISECRETARY/CUERK & 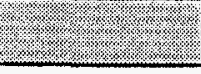 & 7 & 1. & 7. & 1. & 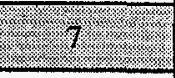 & 2 & 7. \\
\hline Admin Assistants & G010 & 2 & 2 & 2 & 2 & 2 & 2 & 2 \\
\hline Office Clerks (Special) & G030 & 1 & 1 & 1 & 1 & 1 & 1 & 1 \\
\hline Secretaries & G040 & 4 & 4 & 4 & 4 & 4 & 4 & 4 \\
\hline CRAFTS & $\sqrt[3]{1.20}$ & $=16=$ & 10.16 & 1.16 & 16 & $=16$ & 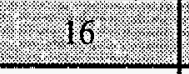 & 16 \\
\hline Electricians & $\mathrm{C} 020$ & 8 & 8 & 8 & 8 & 8 & 8 & 8 \\
\hline Plumbers/Pipefitters & $\mathrm{C} 080$ & 8 & 8 & 8 & 8 & 8 & 8 & 8 \\
\hline LABOR \& GEN WORKERS & 3.2 & 2.81 & -81. & 8.81 & $81=$ & 81 & 81. & 8.81 \\
\hline Firefighters & L010 & 81 & 81 & 81 & 81 & 81 & 81 & 81 \\
\hline TOTAL & & 147.0 & 147.0 & 147 & 147 & 147 & 147 & 147 \\
\hline
\end{tabular}


WHC-SP-1 105, Rev. 2

\section{Distribution Sheet}

$\underline{\mathrm{RL}}$

W. A. Scott (3)

A5-55

WHC

L. C. Brandt

B3-53

D. E. Good (6)

S3-97

O. Johnson

$\mathrm{S} 2-46$

L. L. Powers

H6-30

R. E. Traister

B3-63

Document Processing \& Administration

L8-15

Central Files

A3-88

O.S.T.I. (2)

A3-36 